\title{
A bovine CD18 signal peptide variant with increased binding activity to Mannheimia hemolytica leukotoxin [version 1; peer
} review: 3 approved]

\author{
Aspen M. Workman (D1), Carol G. Chitko-McKown1, Timothy P. L. Smith1, \\ Gary L. Bennett (D1), Theodore S. Kalbfleisch², Veronica Basnayake3, \\ Michael P. Heaton (Di) 1 \\ 1 USDA, US Meat Animal Research Center (USMARC), Clay Center, Nebraska, 68933, USA \\ 2Department of Biochemistry and Molecular Genetics, School of Medicine, University of Louisville, Louisville, Kentucky, 40292, USA \\ ${ }^{3}$ GeneSeek, a Neogen Company, Lincoln, NE, USA
}

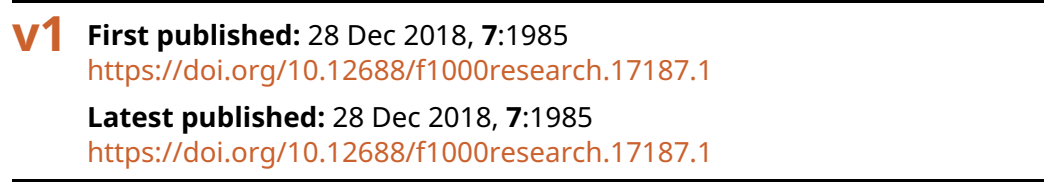

\section{Abstract}

Background: Mannheimia haemolytica is the major bacterial infectious agent of bovine respiratory disease complex and causes severe morbidity and mortality during lung infections. M. haemolytica secretes a protein leukotoxin (Lkt) that binds to the CD18 receptor on leukocytes, initiates lysis, induces inflammation, and causes acute fibrinous bronchopneumonia. Lkt binds the 22-amino acid CD18 signal peptide domain, which remains uncleaved in ruminant species. Our aim was to identify missense variation in the bovine CD18 signal peptide and measure the effects on Lkt binding.

Methods: Missense variants in the integrin beta 2 gene (ITGB2) encoding CD18 were identified by whole genome sequencing of 96 cattle from 19 breeds, and targeted Sanger sequencing of 1238 cattle from 46 breeds. The ability of different CD18 signal peptide variants to bind Lkt was evaluated by preincubating the toxin with synthetic peptides and applying the mixture to susceptible bovine cell cultures in cytotoxicity-blocking assays.

Results: We identified 14 missense variants encoded on 15 predicted haplotypes, including a rare signal peptide variant with a cysteine at position $5\left(C_{5}\right)$ instead of arginine $\left(R_{5}\right)$. Preincubating Lkt with synthetic signal peptides with $C_{5}$ blocked cytotoxicity significantly better than those with $R_{5}$. The most potent synthetic peptide $\left(C_{5}\right.$ PQLLLLAGLLA) had 30-fold more binding activity compared to that with $R_{5}$.

Conclusions: The results suggest that missense variants in the CD18 signal peptide affect Lkt binding, and animals carrying the $C_{5}$ allele may be more susceptible to the effects of Lkt. The results also identify a potent class of non-antibiotic Lkt inhibitors that could potentially
Open Peer Review

\begin{tabular}{cccc} 
Approval Status & \multicolumn{1}{c}{} \\
\hline & 1 & 2 & 3 \\
\hline version 1 & & & \\
28 Dec 2018 & view & view & view
\end{tabular}

1. Alan L. Archibald ID, University of

Edinburgh, Midlothian, UK

2. Holly L. Neibergs ID, Washington State

University, Pullman, USA

3. Jonathan E. Beever, University of Illinois at

Urbana-Champaign, Urbana, USA

University of Tennessee Institute of

Agriculture, Knoxville, USA

Any reports and responses or comments on the article can be found at the end of the article. 
protect cattle from cytotoxic effects during acute lung infections.

\section{Keywords}

Cattle, CD18, integrin beta 2, missense mutation, signal peptide

variants, bacterial leukotoxin, bovine respiratory disease, shipping

fever, Mannheimia haemolytica

Corresponding authors: Aspen M. Workman (aspen.workman@ars.usda.gov), Michael P. Heaton (mike.heaton@ars.usda.gov)

Author roles: Workman AM: Conceptualization, Formal Analysis, Investigation, Methodology, Resources, Validation, Visualization, Writing - Original Draft Preparation, Writing - Review \& Editing; Chitko-McKown CG: Conceptualization, Investigation, Methodology, Resources, Writing - Review \& Editing; Smith TPL: Methodology, Resources, Writing - Review \& Editing; Bennett GL: Formal Analysis, Methodology, Resources, Software, Validation, Writing - Review \& Editing; Kalbfleisch TS: Data Curation, Formal Analysis, Methodology, Resources, Software, Validation, Writing - Review \& Editing; Basnayake V: Investigation, Methodology, Resources, Validation, Writing Review \& Editing; Heaton MP: Conceptualization, Data Curation, Formal Analysis, Investigation, Methodology, Resources, Validation, Visualization, Writing - Original Draft Preparation, Writing - Review \& Editing

Competing interests: Co-author V.B. is a full-time employee at GeneSeek, a Neogen company that provides agrigenomic and veterinary diagnostic services. There are no patents, products in development, or marketed products to declare. These interests do not alter the authors' adherence to all the journal's policies on sharing data and materials.

Grant information: Funding for this research was provided by the USDA, ARS appropriated projects 5438-32000-029-00D (CGCM) and 5438-31320-012-00D (TPLS).

The funders had no role in study design, data collection and analysis, decision to publish, or preparation of the manuscript.

Copyright: (c) 2018 Workman AM et al. This is an open access article distributed under the terms of the Creative Commons Attribution License, which permits unrestricted use, distribution, and reproduction in any medium, provided the original work is properly cited.

How to cite this article: Workman AM, Chitko-McKown CG, Smith TPL et al. A bovine CD18 signal peptide variant with increased binding activity to Mannheimia hemolytica leukotoxin [version 1; peer review: 3 approved] F1000Research 2018, 7:1985 https://doi.org/10.12688/f1000research.17187.1

First published: 28 Dec 2018, 7:1985 https://doi.org/10.12688/f1000research.17187.1 


\section{Introduction}

Mannheimia haemolytica is the major bacteria associated with bovine respiratory disease, a heterogeneous complex of highly infectious pathogens that are the primary cause of morbidity, mortality, and economic loss affecting beef and dairy cattle industries $^{1,2} . M$. haemolytica is a commensal bacterium found in tonsillar crypts and the upper respiratory tracts of healthy cattle ${ }^{3,4}$. Exposure to environmental stresses or co-infection with other viral or bacterial pathogens can impair host defenses allowing $M$. haemolytica to proliferate and colonize the lungs where infection causes acute fibrinonecrotic pleuropneumonia ${ }^{2,5,6}$. This bacterium expresses a variety of virulence factors that contribute to disease pathogenesis in the lungs. However, leukotoxin (Lkt) is the primary virulence factor contributing to the clinical signs and severe lung damage observed following infection ${ }^{7,8}$. Within hours of bacterial colonization of the lung, large numbers of polymorphonuclear leukocytes (PMN) infiltrate the airways $^{2,9}$. Lkt binds to the bovine CD18 subunit of the heterodimeric integrins on the surface of PMN causing cell lysis and the release of pro-inflammatory cytokines, proteolytic enzymes, and reactive oxygen intermediates that intensify local inflammation ${ }^{6,10-13}$. Experimental depletion of PMN prior to infection ${ }^{14}$, or infection with a Lkt-deletion mutant of $M$. haemolytica, ${ }^{7,8}$, results in decreased morbidity and reduced lung lesions in calves. Thus, the interaction between the toxin and its receptor is critical to the pathogenesis of $M$. haemolytica infection and is a potential intervention point for the prevention of disease.

A 13-amino acid sequence in the CD18 signal peptide has been identified as the site which binds to bacterial $\mathrm{Lkt}^{10}$. The 22-amino acids that comprise the CD18 signal peptide remain uncleaved in leukocytes of ruminant species due to a conserved cleavageinhibiting glutamine residue at position $18\left(\mathrm{Q}_{18}\right)$ of the propeptide ${ }^{10}$. In non-ruminant species, such as human and murine, leukocytes are naturally resistant to Lkt because their CD18 signal peptides undergo cleavage due to a glycine residue at position $18\left(\mathrm{G}_{18}\right)$. However, when murine cell lines were transfected with bovine ITGB2, the gene which encodes CD18, they became susceptible to Lkt. When site-directed mutagenesis of ITGB2 was used in the same murine cell lines to change the bovine $\mathrm{Q}_{18}$ residue to $\mathrm{G}_{18}$, the bovine CD18 signal peptide was cleaved and the murine cells once again became resistant to Lkt-induced lysis ${ }^{10}$. This strategy was taken further with gene-editing, showing that leukocytes isolated from a cloned bovine fetus, homozygous for CD18 $\mathrm{G}_{18}$, were unaffected by Lkt exposure because the signal peptide was cleaved and unavailable for Lkt binding ${ }^{15}$. Thus, retention of the ruminant CD18 signal peptide appears to be the cause of Lkt sensitivity in leukocytes.

Naturally occurring CD18 amino acid sequence variation can also interfere with Lkt cytotoxicity. In Holstein dairy cattle, a CD18 substitution of glycine for aspartate at polypeptide position 128 in the extracellular I-like domain of CD18 causes bovine leukocyte adhesion deficiency (BLAD) in homozygous animals $^{16,17}$. These calves do not express functional CD18 on the surface of their leukocytes and have significantly reduced sensitivity to Lkt compared to control calves ${ }^{18,19}$. We hypothesized that other variation in the CD18 polypeptide sequence, if it exists, may alter the Lkt-CD18 binding interaction or cell signaling and result in differences in lymphocyte sensitivity to $M$. haemolytica Lkt. Thus, the goals of this study were to identify CD18 protein variants encoded by ITGB2 in U.S. cattle breeds, and evaluate the effects of signal peptide variants on Lkt binding. We report the identification of 15 predicted protein variants, including one with enhanced Lkt binding.

\section{Methods}

\section{Ethics statement}

All animal procedures were reviewed and approved by the U.S. Department of Agriculture, Agricultural Research Service, U.S. Meat Animal Research Center (USMARC) Institutional Animal Care and Use Committee (IACUC project number 2.2).

Panels of cattle DNA used for missense mutation discovery Two panels of DNAs were used to determine ITGB2 genotypes from U.S. cattle. The first was a previously described panel of 96 unrelated beef cattle from 19 popular U.S. beef breeds that had already been characterized by whole-genome sequencing ${ }^{20}$. This identified predicted coding changes throughout the ITGB2 gene. The second panel included a non-overlapping set of 1142 unrelated cattle from 46 breeds, on which targeted Sanger sequencing was performed to identify any predicted coding changes in the signal peptide region and the region containing the D128G variant causing BLAD (ITGB2 exons 2, 3, and 5). Briefly, the first panel of 96 beef cattle (USMARC Beef Cattle Diversity Panel version 2.9 [MBCDPv2.9]) was based on commerciallyavailable purebred registered sires. Pedigrees were obtained from leading suppliers of U.S. beef cattle semen and analyzed to identify unrelated individuals for inclusion. The number of sires representing each breed (four, five, or six) was based on their numbers of registered progeny circa 2000: Angus $(n=6)$, Hereford $(n=6)$, Charolais $(n=6)$, Simmental $(n=6)$, Red Angus $(n=6)$, Limousin $(n=6)$, Gelbvieh $(n=6)$, Brangus $(n=5)$, Beefmaster $(n=5)$, Salers $(n=5)$, Shorthorn $(n=5)$, Maine-Anjou $(n=5)$, Brahman $(n=5)$, Chianina $(n=4)$, Texas Longhorn $(n=4)$, Santa Gertrudis $(n=4)$, Braunvieh $(n=4)$, Corriente $(n=4)$, and Tarentaise $(n=4)$. On the basis of the number of registered progeny, the breeds were estimated to represent greater than $99 \%$ of the germplasm used in the US beef cattle industry, contain more than 187 unshared haploid genomes, and allow a $95 \%$ probability of detecting any allele with a frequency greater than $0.016^{21}$.

The second panel of 1142 cattle consisted of samples from male and female registered purebred cattle with diverse pedigrees from 46 breeds. Samples were from semen, blood, or hair follicles, depending on gender and availability ${ }^{22}$. Where possible, animals within breed were chosen so they did not share parents or grandparents, and none were closely related to the 96 sires in the MBCDPv2.9. The breeds used in the second panel were: Angus $(\mathrm{n}=24)$, Ankole-Watusi $(\mathrm{n}=20)$, Ayrshire $(\mathrm{n}=24)$, Beefmaster $(\mathrm{n}=24)$, Belgian Blue $(\mathrm{n}=24)$, Blonde d'Aquitaine $(\mathrm{n}=24)$, Brahman $(n=23)$, Brahmousin $(n=24)$, Brangus $(n=24)$, Braunvieh $(\mathrm{n}=24)$, Brown Swiss $(\mathrm{n}=26)$, Charolais $(\mathrm{n}=24)$, Chianina $(n=24)$, Corriente $(n=24)$, Devon $(n=23)$, Dexter $(n=22)$, Gelbvieh $(n=23)$, Guernsey $(n=23)$, Hereford $(n=24)$, Highland 
( $\mathrm{n}=24)$, Holstein $(\mathrm{n}=81)$, Indu-Brazil $(\mathrm{n}=25)$, Jersey $(n=29)$, Limousin $(n=24)$, Maine-Anjou $(n=24)$, Marchigiana $(\mathrm{n}=24)$, Mini-Hereford $(\mathrm{n}=24)$, Mini-Zebu $(\mathrm{n}=24)$, Montbeliard $(\mathrm{n}=24)$, Murray Grey $(\mathrm{n}=20)$, Nelore $(\mathrm{n}=24)$, Piedmontese $(\mathrm{n}=25)$, Pinzgauer $(\mathrm{n}=23)$, Red Angus $(\mathrm{n}=23)$, Red Poll $(n=24)$, Romagnola $(n=24)$, Salers $(n=24)$, Santa Gertrudis $(n=24)$, Senepol $(n=23)$, Shorthorn $(n=23)$, Simmental $(n=23)$, Tarentaise $(n=24)$, Texas Longhorn $(n=23)$, Texas Longhorn, Cattlemen's Texas Longhorn Registry (CTLR, $n=19$ ), Tuli $(n=23)$, and Wagyu $(n=22)$.

\section{DNA sequencing and single nucleotide polymorphism (SNP) genotyping}

Unless otherwise indicated, reagents were molecular-biology grade. DNA from whole blood samples was extracted by use of a solid-phase system incorporating either spin-columns or 96-well microtitration plates according to the manufacturer's instructions (Qiagen Inc., Germantown, MD, USA). DNA from liver, muscle, skin, or hair samples was extracted by standard procedures $^{22}$. Briefly, minced tissue $(35 \mathrm{mg}$ ) or hair follicles (100 trimmed bulbs) were suspended in $2.5 \mathrm{~mL}$ of a lysis solution containing $10 \mathrm{mM}$ TrisCl, $400 \mathrm{mM} \mathrm{NaCl}, 2 \mathrm{mM}$ EDTA, $1 \% \mathrm{wt} / \mathrm{vol}$ sodium dodecyl sulfate, RNase A (250 ug/ml; Sigma-Aldrich, St. Louis, MO, USA), $\mathrm{pH}$ 8.0. The solution was incubated at $37^{\circ} \mathrm{C}$ with gentle agitation. After 1 hour, $1 \mathrm{mg}$ proteinase $\mathrm{K}$ was added (Sigma-Aldrich) and the solution was incubated overnight at $37^{\circ} \mathrm{C}$ with continued agitation. The solution was transferred to $15 \mathrm{ml}$ tube containing $3 \mathrm{ml}$ of a phase-separation gel (high-vacuum grease, Dow Corning Corporation, Midland, MI, USA) and extracted twice with 1 vol of phenol:chloroform:isoamyl alcohol (25:24:1), and once with 1 vol of chloroform before precipitation with 2 vol of $100 \%$ ethanol. The precipitated DNA was washed once in $70 \%$ ethanol, briefly air dried, and dissolved in a solution of $10 \mathrm{mM}$ TrisCl, $1 \mathrm{mM}$ EDTA (TE, $\mathrm{pH}$ 8.0).

DNA from commercial bull semen was extracted similarly, with slight modification ${ }^{23}$. Briefly, three $0.5 \mathrm{ml}$ straws of commercial semen from a single animal were pooled, and the cells were collected by centrifugation for $5 \mathrm{~min}$ at $1000 \mathrm{x} \mathrm{g}$. The cell pellet was washed three times in $1 \mathrm{ml}$ of a wash solution (TE with $100 \mathrm{mM} \mathrm{NaCl}, \mathrm{TNE}$ ) and suspended in $1 \mathrm{ml}$ of the same solution with $1 \% \mathrm{wt} / \mathrm{vol}$ sodium dodecyl sulfate, $1 \mathrm{mg}$ proteinase $\mathrm{K}$ (Sigma-Aldrich), and $40 \mathrm{mM}$ dithiothreitol (DTT). This $1 \mathrm{ml}$ lysis solution was incubated overnight at $37^{\circ} \mathrm{C}$, transferred to a $15 \mathrm{ml}$ tube containing $1.5 \mathrm{ml}$ of TNE with $40 \mathrm{mM} \mathrm{DTT}$, and $3 \mathrm{ml}$ of a phase-separation gel, extracted twice with 1 vol of phenol:chloroform:isoamyl alcohol (25:24:1), and once with 1 vol of chloroform before precipitation with 0.1 vol of $3 \mathrm{M}$ sodium acetate ( $\mathrm{pH} 5.2)$ and 2 vol of $100 \%$ ethanol. The precipitated DNA was washed once in $70 \%$ ethanol, briefly air dried, and dissolvedin a solution TE.

PCR-amplified fragments of genomic DNA from ITGB2 exons 2, 3 and 5, encoding the CD18 signal peptide sequence and the region containing the known variant causing BLAD, were produced for Sanger sequencing in 96 or 384-well plates. A standard $25 \mu \mathrm{l}$ amplification reaction contained $2.5 \mu \mathrm{l}$ of genomic DNA in TE $(10 \mathrm{ng} / \mu \mathrm{l}), 12.5 \mu \mathrm{l}$ of a concentrated PCR cocktail (Maxima
Hot Start, Thermo Fisher Scientific, Waltham, MA, USA), $1.25 \mu 1$ each of an oligonucleotide primer stock solution (100 $\mathrm{uM}$, in TE), $1 \mu \mathrm{l}$ dimethyl sulfoxide (Sigma-Aldrich), and $6.5 \mu \mathrm{l}$ water. The sense and antisense primer sequences for exons 2 and 3 were 5'-AGG-GAG-ACT-GAC-CTG-TGT-G-3' and 5'-CTG-GGAAGC-AGA-GTG-ATA-GT-3', respectively (USMARC primer no. 89878 and 89880). The sense and antisense primer sequences for exon 5 were 5'-AGA-GAG-ATC-CAG-GTA-GAA-CTG-3' and 5'-GTG-CAG-AGG-TGC-AGA-GGT-G-3', respectively (USMARC primer no. 89887 and 89889). The final concentration of each primer was of $5 \mathrm{uM}$ (Integrated DNA Technologies, Inc., Coralville, IA, USA). PCR was performed with either the PTC 200, the PTC 220 Dyad, or the PTC 225 Tetrad thermal cycler chassis (MJ Research, Watertown, MA, USA). Reactions were denatured at $94^{\circ} \mathrm{C}$ for $15 \mathrm{~min}$, subjected to 45 cycles of denaturation at $94^{\circ} \mathrm{C}$ for $20 \mathrm{~s}$, annealed at $58^{\circ} \mathrm{C}$ for $30 \mathrm{~s}$, and extended at $72^{\circ} \mathrm{C}$ for $1 \mathrm{~min}$. After cycling the final products were extended at $72^{\circ} \mathrm{C}$ for $3 \mathrm{~min}$ before storage at $4^{\circ} \mathrm{C}$. A $5 \mu \mathrm{l}$ portion of each amplified product was analyzed by agarose gel electrophoresis $(0.8 \%)$ in buffer containing $90 \mathrm{mM}$ Tris-borate ( $\mathrm{pH} 8.0$ ), $2 \mathrm{mM}$ ethylenediamine tetraacetic acid, and $0.1 \mu \mathrm{g} / \mathrm{ml}$ ethidium bromide. A $6 \mu$ portion of each amplified product was treated with Exonuclease I (1.4 U, New England Biolabs Inc., Ipswich, MA, USA) at $37^{\circ} \mathrm{C}$ for $1 \mathrm{hr}$ in a $13 \mu \mathrm{l}$ reaction volume to digest single-stranded primer oligonucleotides. The Exonuclease I was inactivated with a $65^{\circ} \mathrm{C}$ incubation for $20 \mathrm{~min}$ and the DNA was precipitated with two volumes of $100 \%$ ethanol. The plates were centrifuged at $1800 \mathrm{x}$ g for $30 \mathrm{~min}$, decanted, and air dried.

Sequencing reactions were accomplished by dissolving air-dried DNA pellets in $5 \mu$ of sequencing reaction cocktail containing $0.25 \mu \mathrm{l}$ of dye terminators (DYEnamic ET Dye terminators, Amersham Biosciences, Piscataway, NJ, USA), $1.75 \mu$ l dye terminator dilution buffer (Amersham Biosciences), $2 \mu$ l oligonucleotide primer $(1.6 \mu \mathrm{M}$ stock solution in water), and $1 \mu \mathrm{l}$ water according to the manufacturer's instructions. The final oligonucleotide concentration was $640 \mathrm{nM}$. Reactions were denatured at $96^{\circ} \mathrm{C}$ for $30 \mathrm{~s}$, subjected to 26 cycles of denaturation at $96^{\circ} \mathrm{C}$ for $10 \mathrm{~s}$, annealed at $50^{\circ} \mathrm{C}$ for $5 \mathrm{~s}$, and extended at $60^{\circ} \mathrm{C}$ for $4 \mathrm{~min}$. After cycling the final products were stored at $4{ }^{\circ} \mathrm{C}$ until the DNA was precipitated with $22 \mu \mathrm{l}$ of $70 \%$ isopropyl alcohol. The plates were centrifuged, at $1800 \mathrm{x} \mathrm{g}$ for $30 \mathrm{~min}$, decanted, and the samples were washed with $22 \mu \mathrm{l}$ of $70 \%$ ethanol. The plates were centrifuged again, decanted, air dried, sealed with foil, and stored at $-20^{\circ} \mathrm{C}$ until use. Sequencing reactions were resolved by capillary electrophoresis as described by the manufacturer (3730xl DNA Analyzer, Applied Biosystems, Foster City, CA, USA). Animal sequences from both strands were analyzed with polyphred software version $6.18^{24}$ in conjunction with the phred/phrap/ consed software version $29^{25-27}$.

\section{Whole genome sequencing of BL3 cells}

Whole genome sequencing of BL3 cells (a bovine lymphoma cell line; kindly provided by Dr. Subramaniam Srikumaran) was accomplished with methods as described elsewhere ${ }^{20}$. Briefly, genomic DNA was used to make a 500 bp paired-end library and sequenced with a massively parallel sequencing machine and 
high-output kits (NextSeq500, two by 150 paired-end reads, Illumina, San Diego, CA, USA) until a minimum of $40 \mathrm{~GB}$ of data with greater than Q20 quality, was collected. After sequencing, the raw reads were filtered to remove adaptor sequences, contaminating dimer sequences, and low-quality reads. The DNA sequence alignment process was similar to that previously reported $^{20}$. FASTQ files were aggregated for each sample and DNA sequences were aligned individually to the bovine reference assembly UMD3.128 with the Burrows-Wheeler aligner (BWA) aln algorithm version 0.7.12 $2^{29}$, then merged and collated with bwa sampe. The resulting sequence alignment map (SAM) files were converted to binary alignment map (BAM) files, and subsequently sorted via SAMtools version $0.1 .18^{30}$. Potential PCR duplicates were marked in the BAM files using the Genome Analysis Toolkit (GATK) version 1.5-32-g2761da9 ${ }^{31}$. Regions in the mapped dataset that would benefit from realignment due to small indels were identified with the GATK module RealignerTargetCreator, and realigned using the module IndelRealigner. The BAM files produced at each of these steps were indexed using SAMtools. The resulting indexed BAM files were made available via the USMARC WGS browser and the raw reads for the BL3 cell line were deposited at NCBI BioProject PRJNA325058, BioSample number SAMN05217649. Mapped datasets for each sample were individually genotyped with the GATK UnifiedGenotyper with arguments "--alleles" set to the VCF file (Extended Data File S1) 32, "--genotyping_mode" set to "GENOTYPE_GIVEN_ALLELES", and "--output_mode" set to "EMIT_ALL_SITES". Lastly, some SNP variants were identified manually by inspecting the sequence with IGV software version 2.1.28 $8^{33,34}$ (described in the Methods section entitled 'Identifying protein variants encoded by ITGB2'). In these cases, read depth, allele count, allele position in the read, and quality score were considered when the manual genotype determination was made.

\section{Identifying predicted protein variants encoded by bovine ITGB2}

Aligned WGS data from 96 sires of MBCDPv2.9 were visually analyzed in the ITGB2 coding region to identify potential CD18 protein variants. Viewing the aligned sequences and detecting variants was accomplished with the IGV software and a browser developed for this purpose. Briefly, public internet sites at the USDA, ARS, USMARC were used in combination with open source software installed on a laptop computer and recorded manually in a spreadsheet as previously described ${ }^{20}$. A Java Runtime Environment (Oracle Corporation, Redwood Shores, CA, USA) was first installed on the computer. When links to the data were selected by the user, IGV software ${ }^{33,34}$ was loaded from a third-party site (University of Louisville, Louisville, KY, USA) and aligned DNA sequence reads were displayed in the context of the bovine UMD3.1 reference genome assembly. For viewing ITGB2 gene variants, WGS from a set of eight animals of different breeds was loaded, and the IGV browser was directed to the appropriate genome region by entering "ITGB2" in the search field. The IGV zoom function was used to view the first exon at nucleotide resolution with the [show translation] option selected in IGV. An example of the alignment view for ITGB2 codon 27 with eight animals is shown in Extended data, Figure $\mathrm{S}^{35}$.

The exon sequences were visually scanned for polymorphisms predicted to alter amino acid sequences, including missense, nonsense, frameshift, splice site, and insertion/deletion mutations. An in silico analysis of other potential splice-affecting variants was not performed as there are no consensus guidelines on the selection of programs or protocols to interpret the predicted results in cattle. Once identified, the variant nucleotide position was viewed and recorded for all 96 animals. The codons affected by SNP alleles were translated into their corresponding amino acids with IGV, codon tables, and knowledge of the CD18 protein sequence (NP_786975). Haplotype phases of predicted polypeptide variants were unambiguously assigned with homozygous individuals, and those with only one variant amino acid. A maximum parsimony phylogenetic tree was manually constructed from the unambiguously phased protein variants and used to infer phases in the remaining variants with maximum parsimony assumptions.

\section{MALDI-TOF MS genotyping of 14 ITGB2 missense mutations}

A single multiplex assay was designed for the 14 ITGB2 missense SNPs with software provided by the manufacturer (Agena Biosciences, San Diego, CA, USA). The oligonucleotide sequences and assay conditions are provided in Table S1. After design and validation with bovine control DNAs for each SNP, the DNA from the 96 bulls in the MBCDPv2.9 diversity panel were tested in a blinded experiment. Assay design and genotyping was performed at GeneSeek (Lincoln, NE, USA) with the MassARRAY platform and iPLEX Gold chemistry according to the manufacturer's instructions (Agena Biosciences).

\section{Lkt preparation, gel electophoresis, and protein immunoblotting}

M. haemolytica strains for toxin production were isolated from cattle with severe fibrinous pleuropneumonia in feedlot environments and had complete closed whole genome sequence assemblies available at NCBI. M. haemolytica strain 89010807 N serotype A1 $(l k t A+)$ has been widely used for Lkt production for in vitro cytotoxicity assays and has the added advantage of being the parent strain of an isogenic leukotoxin deletion mutant $(\mathrm{lktA}-)^{36,37}$. A second strain, $M$. haemolytica strain USDA-ARS-USMARC183 serotype A1, was isolated from an animal that was part of a high-mortality respiratory disease outbreak in a Kansas feedlot in 1991 and represents the first strain with a complete closed genome assembly ${ }^{38}$; however, it had not previously been used in in vitro assays.

Isolates were maintained on Brain Heart Infusion (BHI) agar (Sigma-Aldrich) frozen stocks were kept in BHI broth with 20\% glycerol at $-80^{\circ} \mathrm{C}$. RPMI 1640 medium (without Phenol Red and L-glutamine, Sigma-Aldrich) and semi-defined medium 2 (SDM2) were used for batch culture production of Lkt. SDM2 is an amino acid-limited culture medium supplemented with cysteine, glutamine, ferric iron, and manganese and was previously shown to greatly improve Lkt production in aerobic batch culture ${ }^{39}$. For Lkt production, a single, 24-hour colony isolate from BHI agar was inoculated into $5 \mathrm{ml}$ BHI broth in a $10 \mathrm{ml}$ culture tube and incubated overnight at $37^{\circ} \mathrm{C}$ in $5 \% \mathrm{CO}_{2}$ without shaking. The following morning, $1 \mathrm{ml}$ of BHI liquid culture was inoculated into $100 \mathrm{ml}$ of fresh culture medium in a $300 \mathrm{ml}$ Delong-style Erlenmeyer flask with baffles (Corning, Inc., Corning, $\mathrm{NY}$, USA) and incubated at $37^{\circ} \mathrm{C}, 250 \mathrm{rpm}$, in $5 \% \mathrm{CO}_{2}$. At intervals, 
$14 \mathrm{ml}$ samples were removed and centrifuged at $13,100 \mathrm{x} \mathrm{g}$ for $10 \mathrm{~min}$ at $4^{\circ} \mathrm{C}$. The clarified supernatant was decanted, flash frozen in liquid nitrogen and stored at $-80^{\circ} \mathrm{C}$ until use.

Lkt and other proteins secreted into the growth media by $M$. haemolytica were analyzed by SDS-PAGE. Clarified supernatants were precipitated with one volume of acetone on ice for $30 \mathrm{~min}$, followed by centrifugation at $20,800 \mathrm{x} \mathrm{g}$ for 5 minutes at room temperature, and air dried $30 \mathrm{~min}$. Sedimented proteins were dissolved in a commercial sample buffer with lithium dodecyl sulfate and dithiothreitol and used per the manufacture instructions (Thermo Fisher Scientific). Samples were heated to $70^{\circ} \mathrm{C}$ for 10 minutes and loaded on $4-12 \%$ precast polyacrylamide Bis-Tris gels (Thermo Fisher Scientific) at run 160 volts for approximately $35 \mathrm{~min}$ in 2-[N-morpholino] ethanesulfonic acid (MES) SDS running buffer (Thermo Fisher Scientific). Proteins sorted by SDS PAGE were stained with coomassie-dye reagent (GelCode Blue, Thermo Fisher Scientific) and destained in water. Prestained protein standards (Novex Sharp, Thermo Fisher Scientific) were used to estimate molecular weights of M. haemolytica proteins from clarified supernatants. Image J software (version $1.52 \mathrm{~A}$ ) was used to estimate relative proportions of protein bands on coomassie-stained page gel $^{40}$.

For protein immunoblots (western blots), proteins from SDSPAGE gels were electrophoretically transferred to $0.2 \mu \mathrm{m}$ polyvinylidene difluoride membranes (PVDF, Invitrolon, Thermo Fisher Scientific) with a Mini Blot Module (Thermo Fisher Scientific) per the manufacturer's instructions. PVDF membranes were wetted in $100 \%$ methanol prior to equilibrating in transfer buffer (Bolt transfer buffer, Thermo Fisher Scientific) and assembling in the blotting apparatus. Proteins were transferred to membranes for $60 \mathrm{~min}$ at a constant voltage of $20 \mathrm{~V}$. Blots were removed from the apparatus and incubated in a blocking reagent (StartingBlock(PBS), Thermo Fisher Scientific), for $60 \mathrm{~min}$ at room temperature with gentle agitation. This solution was replaced with a fresh blocking reagent that had a rabbit polyclonal Ltk antibody at a concentration of $1 \mu \mathrm{g} / \mathrm{ml}$ (M. haemolytica Lkt Antibody, catalog number LS-C369014, LifeSpan, BioSciences, Inc, Seattle, WA, USA) and incubated as above for $60 \mathrm{~min}$. The primary Lkt antibody was washed three times in for 10 min each in 25 $\mathrm{mM}$ Tris, $0.15 \mathrm{M} \mathrm{NaCl}, 0.05 \%$ Tween-20, pH 7.5 (TBS Tween20, Thermo Fisher Scientific). After washing, a goat antirabbit IgG antibody conjugated to horseradish peroxidase (HRP) (catalog number ab97040, Abcam, Cambridge, MA, USA) was added at a concentration of $1 \mu \mathrm{g} / \mathrm{ml}$ in blocking reagent and incubated for $60 \mathrm{~min}$ at room temperature with gentle agitation. This secondary anti-rabbit antibody was washed three times for 10 min each in TBS Tween-20 prior to detection with chemiluminescent substrate (Pierce ECL Western Blotting substrate, Thermo Fisher Scientific). The immunoblot was incubated in chemiluminescent substrate for $1 \mathrm{~min}$ and imaged for approximately 5 min (ChemiDoc, Bio-Rad Laboratories, Inc. Hercules, CA, USA).

\section{Cell culture and synthetic peptides}

BL3 cells were propagated in RPMI 1640 medium (Gibco, Thermo Fisher Scientific) supplemented with $10 \%$ fetal bovine serum (Atlas Biologicals, Fort Collins, CO, USA),1x antibiotic/antimycotic (Gibco, Thermo Fisher Scientific) and 2 mM L-glutamine (Gibco, Thermo Fisher Scientific). Custom bovine CD18 signal peptides (Figure 4-Figure 7) were commercially synthesized, (Thermo Fisher Scientific) purified by preparative high-performance liquid chromatography, and lyophilized. Peptides were dissolved in dimethysulfoxide at a concentration of $10 \mathrm{mg} / \mathrm{ml}$, aliquoted, and stored at $-20^{\circ} \mathrm{C}$.

\section{PBMC and PMN cell isolation}

Primary cells were collected from two mixed breed animals (kept as part of the USMARC cattle population) that were each homozygous for the most common ITGB2 haplotype (variant "1"). For isolation of primary bovine cells, $50 \mathrm{ml}$ of blood were collected by jugular puncture using 16-guage needles into syringes containing EDTA as an anticoagulant. PMN were isolated using a standard hypotonic lysis procedure. Briefly, blood was spun for $25 \mathrm{~min}$ at $1000 \mathrm{x} \mathrm{g}$ at $4^{\circ} \mathrm{C}$. Plasma and buffy coat layers were removed and discarded. Sterile water was added to the red blood cell (RBC) layer to lyse RBC followed by addition of 10X PBS to restore tonicity. PMN were isolated by centrifugation for $10 \mathrm{~min}$ at $250 \mathrm{x} \mathrm{g}$ at $4{ }^{\circ} \mathrm{C}$. The PMN cell pellet was washed three times with 1x PBS and the final cell pellet was resuspended in RPMI 1640 medium.

Peripheral blood mononuclear cells (PBMC) were isolated essentially as described ${ }^{41}$. Briefly, PBMC were isolated over FicollPaque Plus (GE Healthcare Bio-Sciences AB, Uppsala, Sweden), as per the manufacturer's instructions, with modification. Briefly, $15 \mathrm{ml}$ of whole blood mixed 1:1 with PBS was underlayed beneath $14 \mathrm{ml}$ of the density gradient in a $50 \mathrm{ml}$ conical tube. The tubes were then centrifuged for $45 \mathrm{~min}$ at $900 \mathrm{x} \mathrm{g}$ at room temp and with no brake. The PBMC layer was carefully removed and brought up to $45 \mathrm{ml}$ in PBS in a new $50 \mathrm{ml}$ conical tube followed by centrifugation for $15 \mathrm{~min}$ at $400 \mathrm{x}$ g at $4^{\circ} \mathrm{C}$ with high brake. Erythrocytes were removed using RBC lysing buffer (Sigma-Aldrich). The PBMC pellet was further washed three times with $1 \mathrm{x}$ PBS and the final pellet was resuspended in RPMI 1640 medium.

\section{MTT dye-reduction cytotoxicity assay}

The ability of different CD18 signal peptide variants to bind Lkt and inhibit Lkt-induced cytolysis was measured with the MTT dye-reduction cytotoxicity assay ${ }^{10}$. The BL3 cell line was selected because it is the most well-studied, readily available, immortalized cell line susceptible to Ltk-induced cytolysis. CD18 signal peptides were tested at concentrations ranging from $50 \mu \mathrm{M}$ to $0.195 \mu \mathrm{M}$. CD18 signal peptides were diluted using serial 2-fold dilutions in 96-well round bottom plates containing $50 \mu \mathrm{l} /$ well of Lkt at a $50 \%$ toxicity end point titer in colorless RPMI 1640 medium without phenol red (Sigma-Aldrich). Synthetic signal peptides and Lkt preparations were pre-incubated for $1 \mathrm{hr}$ on ice prior to the addition of $5 \times 10^{5}$ cells/wells. These cells were added as a 50 ul suspension with a density of $1 \times 10^{7}$ cells $/ \mathrm{ml}$ in colorless RPMI. Cells were incubated with synthetic signal peptides and Lkt for $1 \mathrm{hr}$ at $37^{\circ} \mathrm{C}$ in $5 \%$ $\mathrm{CO}_{2}$ and subsequently centrifuged at $600 \mathrm{x} \mathrm{g}$ for $7 \mathrm{~min}$ at $4^{\circ} \mathrm{C}$ and the supernatant was removed and discarded. Cells were 
resuspended in $100 \mu \mathrm{l}$ of colorless RPMI and $20 \mu \mathrm{l} 0.5 \%$ MTT (3-(4,5-dimethylthiazol-2-yl)-2,5-diphenyl-2 $\mathrm{H}$-tetrazolium bromide; Sigma-Aldrich) and incubated for $20 \mathrm{~min}$ at $37^{\circ} \mathrm{C}$ in $5 \%$ $\mathrm{CO}_{2}$, centrifuged as before, and the supernatant was removed and discarded. The purple formazan precipitate was then dissolved in $100 \mu \mathrm{l}$ of acid isopropanol $(0.04 \mathrm{~N} \mathrm{HCl}$ in isopropanol). Following a 5 min incubation, cellular debris was pelleted and the supernatant was transferred to a new 96-well plate. The optical density (OD) of the samples was measured at $570 \mathrm{~nm}$ and $690 \mathrm{~nm}$. The background measurement at $690 \mathrm{~nm}$ was then subtracted from the $570 \mathrm{~nm}$ measurement to give the background adjusted OD. The percent cytotoxicity was calculated as follows: (1-(OD of toxin treated cells/OD of cells without toxin)) x 100 . The percent inhibition of cytotoxicity in the presence of synthetic CD18 peptides was calculated as follows: ((percent cytotoxicity in the absence of peptide - percent cytotoxicity in the presence of peptide)/ percent cytotoxicity in the absence of peptide) x 100 . Given normal variability in the assay, values were occasionally obtained outside the range of 0 to $100 \%$ inhibition. Negative values were replaced with 0 and values greater than 100 were replaced with 100 for graphical presentation.

Fresh bovine PBMC or PMN were used for comparison to results obtained using immortalized BL3 cells. Cells were suspended in $50 \mu \mathrm{l}$ colorless RPMI medium and $10 \mu \mathrm{l}$ Biolog Redox Dye $\mathrm{MB}$, containing $500 \mu \mathrm{M}$ water-soluble tetrazolium (Biolog, Hayward, CA, USA). This dye was used because it was found to be more sensitive to changes in cellular respiration when assaying primary cells (data not shown). Cells were incubated for $3 \mathrm{hr}$ at $37^{\circ} \mathrm{C}$ in $5 \% \mathrm{CO}_{2}$, centrifuged as before, and the supernatant was transferred to a clean 96 well plate prior to the OD being measured at $590 \mathrm{~nm}$ and $750 \mathrm{~nm}$. Calculations for percent cytotoxicity and percent inhibition were calculated using background adjusted OD values as described above.

\section{Statistical analyses of $\mathrm{IC}_{50}$ values}

The half maximal inhibitory concentration (IC50) was estimated for each signal peptide variant to compare the concentration of peptide needed to block $50 \%$ of Lkt-induced cytotoxicity of susceptible bovine cells. Univariate nonlinear regression (NLIN procedure, SAS 9.4, SAS Institute Inc., Cary, NC, USA) was used to fit data from three replicates to the following equation: $\mathrm{Y}_{\mathrm{ijk}}=\mathrm{T}+(\mathrm{B}-\mathrm{T}) /\left(1+\left(\mathrm{C}_{\mathrm{j}} / \mathrm{IC} 50_{\mathrm{i}}\right)_{\mathrm{i}}^{\mathrm{S}}\right)+\mathrm{e}_{\mathrm{ijk}}$, where $\mathrm{Y}_{\mathrm{ijk}}$ is the measured Lkt inhibition for the $\mathrm{k}^{\text {th }}$ replicate of the $\mathrm{i}^{\text {th }}$ peptide at the $\mathrm{j}^{\text {th }}$ concentration $\left(\mathrm{C}_{\mathrm{j}}\right)$ of peptide. $\mathrm{T}$ is the estimated maximum, $\mathrm{B}$ is the estimated minimum of the fitted nonlinear relationship between peptide concentration and Lkt inhibition. $S_{i}$ is the slope of the relationship at $\mathrm{IC}_{50}$, the estimated concentration that the $\mathrm{i}^{\text {th }}$ peptide inhibits Lkt-induced cytotoxicity by $50 \%$. e ${ }_{i j k}$ is random variation. Standard errors of IC50, were used for comparisons of estimates.

\section{Results}

Identifying ITGB2 polymorphisms affecting the predicted amino acid sequence of CD18

Bovine ITGB2 consists of 16 exons spanning $29.1 \mathrm{~kb}$ of genomic DNA and encodes a 769 amino acid protein with multiple functional domains (Figure 1A,B). Using software to view the aligned genome sequences from 96 diverse bulls, 13 codons with 14 missense variants were identified (Extended Data Table S2) ${ }^{42}$. There were no frameshifts, splice sites, or indel polymorphisms observed that would affect the predicted amino acid sequence. Two ITGB2 regions of interest were further selected for additional Sanger sequencing in 1142 purebred cattle from 46 breeds: the signal peptide region (exon 2), and the region containing the D128G variant causing BLAD (exon 5). DNA sequence analyses revealed no additional polymorphisms that were predicted to alter the polypeptide sequence, except the previously described D128G variant in Holstein cattle (data not shown). The genotypes were independently verified with a single, multiplexed, MALDI-TOF MS assay for 14 SNPs in the 96 diverse bulls, and in 1142 of 1168 cattle from 46 breeds (Extended Data Table S3) ${ }^{43}$. Thus, in total, there were 14 missense variants identified in 13 codons (Table 1 ).

\section{Determining ITGB2 haplotypes encoding different CD18 polypeptides}

Identifying haplotypes that encode distinct combinations of missense variants on the CD18 polypeptide is important for evaluating their potential function. A total of 15 ITGB2 haplotypes were identified that, when translated, were predicted to encode different CD18 proteins (Table 2). These 15 predicted polypeptide sequences were placed in the context of a maximum parsimony phylogenetic tree (Figure 1C). Haplotypes encoding CD18 protein variants "1 to 7", "9", "13", and "14" were confirmed by their presence in homozygous animals. Haplotypes encoding CD18 protein variants " 8 ", " 10 ", and " 15 " were unambiguously confirmed in animals with only one heterozygous site. However, haplotype phase was ambiguous when the distance between two heterozygous sites exceeds the length of the DNA sequence read (150 bp in these WGS data sets). Thus, haplotypes for the remaining CD18 protein variants " 11 " and " 12 " were tentatively inferred from additional breed-level frequency information. For example, the inferred phase for variant "12" $\left(\mathrm{P}_{155} \mathrm{~L}_{656}\right)$ was only observed in two of 27 Braunvieh cattle that were each heterozygous for both missense variants. However, all 25 of the other Braunvieh cattle sequenced were homozygous for the variant "1" (Table 3 and Extended Data Table S3) ${ }^{43}$. Thus, it was reasonable to infer that $P_{155}$ (exon 5), and $\mathrm{L}_{656}$ (exon 14) are present on one rare haplotype in two animals, rather than on two rare haplotypes in each animal. Similarly, the inferred phase for variant "11" $\left(\mathrm{C}_{5} \mathrm{~L}_{656}\right)$ was only observed in six of 22 Wagyu cattle and each were heterozygous at positions 5 and 656. Since the 22 Wagyu cattle have a variant " 1 " frequency of 0.8 it seems likely that $\mathrm{C}_{5}$ and $\mathrm{L}_{656}$ variants are present on the same chromosome (i.e. diplotype "1,11") rather than split across two chromosomes (i.e., diplotype "5,15"). In spite of the potential for ambiguous haplotype phases with rare variants, the phylogenetic tree of predicted CD18 proteins provides a solid framework for further evaluation.

Evolutionary comparison of CD18 polypeptide sequences Determining the most likely phylogenetic root of the CD18 tree is important for establishing the likely order of mutational 


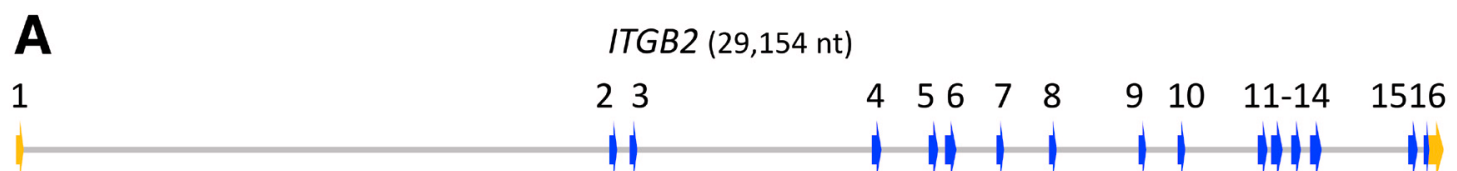

B
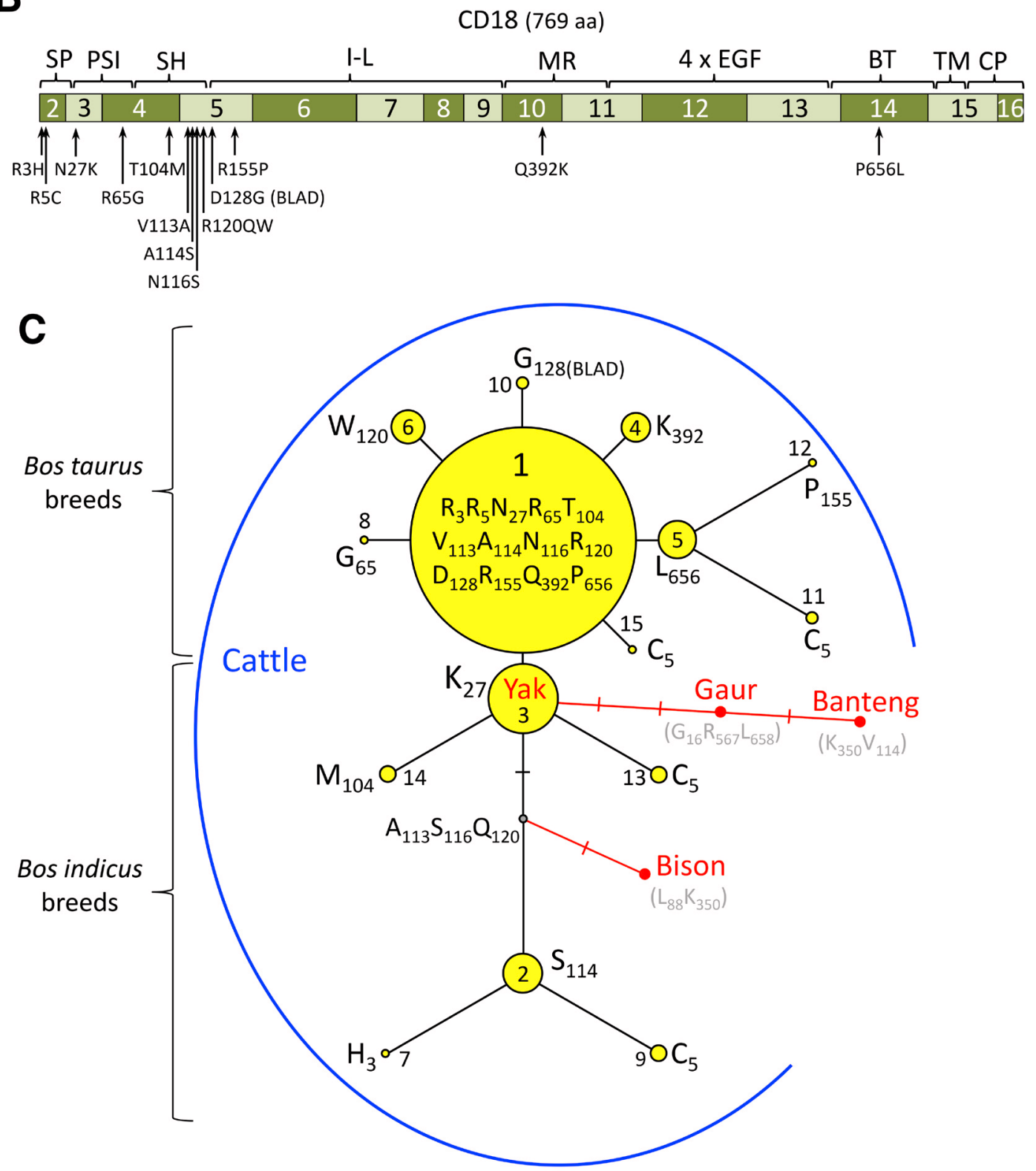

Figure 1. Physical maps of ITGB2, CD18, and rooted maximum parsimony phylogenetic tree of CD18 protein variants in cattle. (A) Genomic DNA map of ITGB2: blue arrows, coding regions of exons; orange arrows, untranslated regions of exons; grey horizontal lines, intron regions. (B) Map of CD18 domains in relationship to missense mutations found in cattle. (C) Rooted maximum parsimony phylogenetic tree of CD18 protein variants from 1142 cattle from 46 breeds with connections to closely-related species. The most frequent CD18 isoform ("variant 1") was used as the reference amino acid sequence for the trees. For "variants 1" through "14", each node in the tree represents a different isoform of CD18 that varies by one amino acid compared to adjacent nodes. The hash marks represent nodes that were inferred but not observed. The areas of the circles are proportional to the overall variant frequency in the cattle tested. Yak CD18 was identical to bovine CD18 "variant 3" and denoted as the most likely root of the phylogenetic tree based on the relationship of CD18 sequences in yak, gaur, banteng, and bison. SP, signal peptide; PSI, plexin-semaphorin-integrin domain; SH, spacer-hybrid domain; I-L, I-like domain; MR, mid-region hybrid domain; EGF, epidermal growth factor-like domain; BT, beta tail domain; TM, transmembrane domain; CP, cytoplasmic domain. 
Table 1. DNA sequence information for 14 bovine ITGB2 missense SNP variants in cattle.

\begin{tabular}{|c|c|c|c|c|c|c|c|c|}
\hline \multirow[b]{2}{*}{$\begin{array}{l}\text { Codon } \\
\text { variant }^{\mathrm{a}}\end{array}$} & \multirow[b]{2}{*}{$\begin{array}{c}\text { Chr 1 } \\
\text { position } \\
\text { (UMD3.1) }\end{array}$} & \multirow[b]{2}{*}{ Exon } & \multirow[b]{2}{*}{$\begin{array}{c}\text { CD18 } \\
\text { domain }\end{array}$} & \multirow[b]{2}{*}{$\begin{array}{l}\text { Consensus } \\
\text { codon } \\
\text { sequence }\end{array}$} & \multirow[b]{2}{*}{$\begin{array}{l}\text { Codon } \\
\text { alleles }^{d}\end{array}$} & \multicolumn{2}{|c|}{$\mathrm{MAF}^{\mathrm{e}}$} & \multirow[b]{2}{*}{ Flanking reference genomic sequence } \\
\hline & & & & & & $\begin{array}{l}\text { Ref. } \\
\text { panel }\end{array}$ & $\begin{array}{l}\text { Ext. } \\
\text { panel }\end{array}$ & \\
\hline $\mathrm{R} 3 \mathrm{H}$ & 145121452 & 2 & $\mathrm{SP}$ & $\mathrm{c} \mathbf{R} \mathrm{c}$ & $\begin{array}{l}\mathbf{c G c}=R \\
\mathrm{CAc}=H\end{array}$ & 0.010 & 0.0004 & $\begin{array}{l}\text { ctggggtctgaagctatgtcactgccccttccctcctcaggacatgctgc } \\
\text { [R]ccagcgeccccagctgctgctcctagcgggcctgcttgccctccagtccg }\end{array}$ \\
\hline $\mathrm{R} 5 \mathrm{C}$ & 145121447 & 2 & $\mathrm{SP}$ & Ygc & $\begin{array}{l}\mathbf{C g c}=R \\
\text { Tgc }=C\end{array}$ & 0.005 & 0.0123 & $\begin{array}{l}\text { gtctgaagctatgtcactgccccttccctcctcaggacatgctgcgecag } \\
\text { [Y]gcccccagctgctgctcctagcgggcctgcttgccctccagtccggtgag }\end{array}$ \\
\hline N27K & 145121043 & 3 & PSI & aas & $\begin{array}{l}a a \mathbf{C}=N \\
a a \mathbf{G}=K\end{array}$ & 0.115 & 0.1187 & $\begin{array}{l}\text { ggctcaccagcccgtgtctctctcccagtcctgtcccaggagtgcaccaa } \\
\text { [S]tacaaggtcageacctgccgggactgcatcgagtcgggccccggctgcgc }\end{array}$ \\
\hline R65G & 145116134 & 4 & PSI & Sga & $\begin{array}{l}\text { Cga }=R \\
\text { Gga }=\mathrm{G}\end{array}$ & 0.005 & 0.0004 & $\begin{array}{l}\text { cccagaacttcacagggcaaggggagcccgactccattcgctgtgacaca } \\
\text { [S]gagcggagctgctgtcaaagggctgcccagctgatgacatcatggaaccc }\end{array}$ \\
\hline $\mathrm{T} 104 \mathrm{M}$ & 145116016 & 4 & $\mathrm{SH}$ & $\mathrm{a} \mathbf{Y g}$ & $\begin{array}{l}\mathrm{aC} g=\mathrm{T} \\
\mathrm{aTg}=\mathrm{M}\end{array}$ & 0.010 & 0.0035 & $\begin{array}{l}\text { ccgggacagccaggcgggcagtcggaagcagctgtccccacaggaagtga } \\
\text { [Y]gctctacctgagaccaggtaggcttggetggctaggggtgggccggccct }\end{array}$ \\
\hline V113A & 145115008 & 5 & $\mathrm{SH}$ & $g \mathbf{Y t}$ & $\begin{array}{l}g \mathbf{T} t=V \\
g \mathbf{C} t=A\end{array}$ & 0.057 & 0.0299 & $\begin{array}{l}\text { gaccaggtggtacaccctgactctctcccaaatcctggcaggtcaggcag } \\
\text { [Y]tgcgttcaatgtgaccttccggagggecaagggctaccccatcgacctgt }\end{array}$ \\
\hline A114S & 145115006 & 5 & $\mathrm{SH}$ & $\mathbf{K} c g$ & $\begin{array}{l}\text { Gcg }=\mathrm{A} \\
\mathbf{T} \mathrm{cg}=\mathrm{S}\end{array}$ & 0.057 & 0.0298 & $\begin{array}{l}\text { ccaggtggtacaccctgactctctcccaaatcctggcaggtcaggcagtt } \\
{[\mathrm{K}] \text { cgttcaatgtgaccttccggagggccaagggctaccccatcgacctgtac }}\end{array}$ \\
\hline N116S & 145114999 & 5 & $\mathrm{SH}$ & $\mathrm{aRt}$ & $\begin{array}{l}\mathrm{a} \mathbf{A} \mathrm{c}=\mathrm{N} \\
\mathrm{a} \mathbf{G}=\mathrm{S}\end{array}$ & 0.057 & 0.0290 & $\begin{array}{l}\text { gtacaccctgactctctcccaaatcctggcaggtcaggcagttgcgttca } \\
\text { [R]tgtgaccttccggagggccaagggctaccccatcgacctgtactacctga }\end{array}$ \\
\hline R120W & 145114988 & 5 & $\mathrm{SH}$ & $\mathbf{Y g g}$ & $\begin{array}{l}\text { Cgg }=R \\
\text { Tgg }=W\end{array}$ & 0.021 & 0.0171 & $\begin{array}{l}\text { ctctctcccaaatcctggcaggtcaggcagttgcgttcaatgtgaccttc } \\
\text { [Y]ggagggccaagggctaccccatcgacctgtactacctgatggacctctcc }\end{array}$ \\
\hline $\mathrm{R} 120 \mathrm{Q}$ & 145114987 & 5 & $\mathrm{SH}$ & $\mathrm{cRg}$ & $\begin{array}{l}\mathrm{CGg}=R \\
\mathrm{CAg}=\mathrm{Q}\end{array}$ & 0.057 & 0.0317 & $\begin{array}{l}\text { tctctcccaaatcctggcaggtcaggcagttgcgttcaatgtgaccttcc } \\
\text { [R]gagggccaagggctaccccatcgacctgtactacctgatggacctctcct }\end{array}$ \\
\hline D128G ${ }^{h}$ & 145114963 & 5 & IL & $g R c$ & $\begin{array}{l}g \mathbf{A} c=D \\
g \mathbf{G}_{c}=G\end{array}$ & -9 & 0.0031 & $\begin{array}{l}\text { ggcagttgcgttcaatgtgaccttccggagggccaagggetaccccatcg } \\
\text { [R]cctgtactacctgatggacctctcctactccatggtggatgacctcgtca }\end{array}$ \\
\hline R155P & 145114882 & 5 & $\mathrm{SH}$ & $\mathrm{cS} g$ & $\begin{array}{l}\mathrm{CGg}=R \\
\mathrm{CCg}=P\end{array}$ & 0.005 & 0.0004 & $\begin{array}{l}\text { catggtggatgacctcgtcaacgtcaagaagctggggggtgacctgctcc } \\
\text { [S]ggccctcaatggcatcaccgagtcgggccgcattggtgaggcagctactc }\end{array}$ \\
\hline Q392K & 145109830 & 10 & $\mathrm{MR}$ & Mag & $\begin{array}{l}\text { Cag }=\mathrm{Q} \\
\text { Aag }=\mathrm{K}\end{array}$ & 0.021 & 0.0131 & $\begin{array}{l}\text { ctgacaccctgaaagtcacctacgactccttctgcagtaacgggaaatcg } \\
\text { [M] ]aggtggaccagcccagaggggactgcgacggcgtccagatcaacgtcccg }\end{array}$ \\
\hline P656L & 145107135 & 14 & BT & $\mathrm{cYg}$ & $\begin{array}{l}C \mathbf{C g}=P \\
C \mathbf{T g}=L\end{array}$ & 0.010 & 0.0270 & $\begin{array}{l}\text { cgccaagaactgcagcgcagcgtgcgggcagacgaagctgctgtccagcc } \\
\text { [Y]ggtgcccggccgcaagtgcaaggagcgcgactccgagggctgctggatga }\end{array}$ \\
\hline
\end{tabular}

${ }^{a}$ All sequences presented are from the sense strand bovine ITGB2 gene. However, in the UMD3.1 reference assembly, ITGB2 oriented in the antisense direction. ${ }^{\circ} \mathrm{CD} 18$ protein domain abbreviations: SP, signal peptide; PSI, plexin-semaphorin-integrin domain; SH, spacer-hybrid domain; IL, I-like domain; and BT, beta-tail domain. ${ }^{~ I U P A C / I U B M B ~ a m b i g u i t y ~ c o d e s ~ u s e d ~ f o r ~ n u c l e o t i d e s: ~} R=a / g, Y=c / t, M=a / c, K=g / t, S=c / g, W=a / t^{46}$. ${ }^{d}$ The major allele is listed first. ${ }^{~ M i n o r ~ a l l e l e ~ f r e q u e n c y ~ i n ~ t h e ~ b e e f ~ c a t t l e ~ d i v e r s i t y ~ p a n e l ~ M B C D P v 2.9 ~}(n=96)$. 'Minor allele frequency in the extended purebred cattle panel with 46 breeds $(n=1142)$. ${ }^{9}$ Allele not detected in the indicated group of cattle. "Missense mutation associated with BLAD ${ }^{17}$.

events. Comparing cattle CD18 precursor protein variants to those from closely related species in the Bos genus indicated that variant " 3 " $\left(\mathrm{K}_{27}\right)$ was the most likely root of the phylogenetic tree (Figure 1C). Cattle are predicted to share a common ancestor with other species in the Bos genus approximately 5 million years ago. In addition, the $\mathrm{K}_{27}$ variant was associated with indicine cattle breeds, while the $\mathrm{N}_{27}$ variant was associated with taurine breeds. For example, the $\mathrm{N}_{27}$ frequency in 840 cattle from 33 taurine breeds was 0.998, while the $\mathrm{K}_{27}$ frequency in 70 Brahman, Indu Brazil, and Nelore cattle was 0.95. Thus, the structure of the rooted tree suggests that CD18 protein variants " 1 " and " 3 " are the ancestral polypeptide sequence of taurine and indicine breeds, respectively. The rooted tree also suggests that the distal nodes represent CD18 variants that have arisen sometime after the split between taurines and indicines, approximately 500,000 years ago.
The conservation of amino acid residues throughout vertebrate species is a measure of their potential impact on protein function. Highly conserved residues are more likely to be indispensable for function and thus, variation at these positions is assumed to be deleterious. The 769 amino acid sequence of cattle CD18 is highly similar to those from yak, sheep, whale, and humans (99, 95, 90, and 83\% identity, respectively). The cattle CD18 sequence is also remarkably similar to chicken, frog, fish, lamprey, and fruit fly $(63,57,49,42$, and $19 \%$ identity, respectively), and has some polypeptide regions that are invariant throughout the Bilateria (Extended Data Table S4) (4) $^{4}$ The 13 variant amino acid positions in the bovine $\mathrm{CD} 18$ precursor protein were compared to those in 35 representative Bilateria species. The aspartate residue at position $128\left(\mathrm{D}_{128}\right)$ is invariant throughout the Bilateria, except in cattle wherein $\mathrm{G}_{128}$ causes the complete loss of CD18 function and results in BLAD in homozygous individuals 
Table 2. Frequencies of predicted full-length CD18 protein variants in U.S. cattle.

\begin{tabular}{|c|c|c|c|c|c|c|c|c|c|c|c|c|c|c|c|}
\hline \multirow[b]{2}{*}{$\begin{array}{c}\text { Protein } \\
\text { variant } \\
\text { code }^{a}\end{array}$} & \multirow{2}{*}{\multicolumn{13}{|c|}{ Variant amino acids ${ }^{b}$}} & \multicolumn{2}{|c|}{$\begin{array}{l}\text { Protein variant } \\
\text { frequency }^{\circ}\end{array}$} \\
\hline & & & & & & & & & & & & & & $\begin{array}{c}\text { Beef cattle } \\
\text { diversity } \\
\text { panel } \\
(n=96)\end{array}$ & $\begin{array}{c}\text { Extended } \\
\text { purebred } \\
\text { cattle } \\
\text { panel } \\
(n=1142)\end{array}$ \\
\hline 1 & R3 & R5 & N2 7 & R65 & $\mathrm{T} 104$ & V113 & A114 & N116 & R120 & D128 & R155 & Q392 & P656 & 0.828 & 0.820 \\
\hline 2 & R3 & R5 & K27 & R65 & T104 & A113 & S114 & s116 & Q120 & D128 & R155 & Q392 & P65 6 & 0.042 & 0.025 \\
\hline 3 & R3 & R5 & K27 & R65 & T104 & V113 & A114 & N116 & R120 & D128 & R155 & Q392 & P 656 & 0.047 & 0.081 \\
\hline 4 & R3 & R5 & N27 & R65 & T104 & V113 & A114 & N116 & R120 & D128 & R155 & K392 & P65 6 & 0.021 & 0.013 \\
\hline 5 & R3 & R5 & N27 & R65 & T104 & V113 & A114 & N116 & R120 & D128 & R155 & Q392 & L656 & 0.005 & 0.024 \\
\hline 6 & R3 & R5 & N27 & R65 & T104 & V113 & A114 & N116 & พ120 & D128 & R155 & Q392 & P65 6 & 0.021 & 0.017 \\
\hline 7 & н3 & R5 & K27 & R65 & $\mathrm{T} 104$ & A113 & $\mathrm{S} 114$ & S116 & Q120 & D128 & R155 & Q392 & P656 & 0.010 & $-{ }^{d}$ \\
\hline 8 & R3 & R5 & N27 & G65 & T104 & V113 & A114 & N116 & R120 & D128 & R155 & Q392 & P65 6 & 0.005 & - \\
\hline 9 & R3 & C5 & K27 & R65 & $\mathrm{T} 104$ & A113 & $\mathrm{S} 114$ & $\mathrm{~s} 116$ & Q120 & D128 & R155 & Q392 & P656 & 0.005 & 0.004 \\
\hline 10 & R3 & R5 & N27 & R65 & $\mathrm{T} 104$ & V113 & A114 & N116 & R120 & G128 & R155 & Q392 & P656 & - & 0.003 \\
\hline 11 & R3 & C5 & N27 & R65 & T104 & V113 & A114 & N116 & R120 & D128 & R155 & Q392 & L656 & - & 0.003 \\
\hline 12 & R3 & R5 & N27 & R65 & $\mathrm{T} 104$ & V113 & A114 & N116 & R120 & D128 & P155 & Q392 & L656 & 0.005 & - \\
\hline 13 & R3 & C5 & K27 & R65 & T104 & V113 & A114 & N116 & R120 & D128 & R155 & Q392 & P656 & - & 0.005 \\
\hline 14 & R3 & R5 & K27 & R65 & M104 & V113 & A114 & N116 & R120 & D128 & R155 & Q392 & P656 & 0.010 & 0.004 \\
\hline 15 & R3 & C5 & N27 & R65 & T104 & V113 & A114 & N116 & R120 & D128 & R155 & Q392 & P656 & - & 0.001 \\
\hline
\end{tabular}

${ }^{a} \mathrm{CD} 18$ protein variant allele definitions are shown in Figure 1C. "The red bold residues are those differing from "variant 1". "The coefficient of

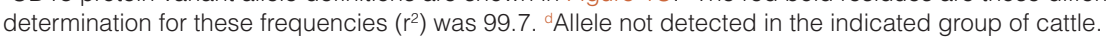

Table 3. Frequencies of predicted CD18 protein variants in 46 U.S. breeds.

\begin{tabular}{|c|c|c|c|c|c|c|c|c|c|c|c|c|c|c|c|c|c|}
\hline \multirow[b]{2}{*}{ Breed group } & \multirow[b]{2}{*}{$\begin{array}{c}\text { Animals } \\
\text { typed } \\
(n=1142)\end{array}$} & \multirow[b]{2}{*}{$\mathrm{C5}^{\mathrm{b}}$} & \multicolumn{10}{|c|}{ CD18 protein variant allele frequency } & \multirow[b]{2}{*}{$11^{\mathrm{b}}$} & \multirow[b]{2}{*}{12} & \multirow[b]{2}{*}{$13^{b}$} & \multirow[b]{2}{*}{14} & \multirow[b]{2}{*}{$15^{b}$} \\
\hline & & & 1 & 2 & 3 & 4 & 5 & 6 & 7 & 8 & $9^{b}$ & $10^{c}$ & & & & & \\
\hline Angus & 24 & - & 0.96 & - & - & 0.04 & - & - & - & - & - & - & - & - & - & - & - \\
\hline $\begin{array}{l}\text { Ankole- } \\
\text { Watusi }\end{array}$ & 20 & - & 0.25 & - & 0.75 & - & - & - & - & - & - & - & - & - & - & - & - \\
\hline Ayrshire & 24 & - & 1.00 & - & - & - & - & - & - & - & - & - & - & - & - & - & - \\
\hline Beefmaster & 24 & - & 0.88 & 0.08 & 0.02 & - & - & - & - & - & - & - & - & - & - & 0.02 & - \\
\hline Belgian Blue & 24 & - & 0.90 & - & - & 0.04 & 0.06 & - & - & - & - & - & - & - & - & - & - \\
\hline $\begin{array}{l}\text { Blonde } \\
\text { d'Aquitaine }\end{array}$ & 24 & - & 0.77 & - & - & 0.04 & 0.08 & 0.10 & - & - & - & - & - & - & - & - & - \\
\hline Brahman & 23 & - & 0.11 & 0.27 & 0.58 & - & 0.02 & - & 0.02 & - & - & - & - & - & - & - & - \\
\hline Brahmousin & 24 & 0.10 & 0.71 & 0.06 & 0.13 & - & - & - & - & - & 0.10 & - & - & - & - & - & - \\
\hline Brangus & 24 & - & 0.55 & 0.09 & 0.21 & 0.15 & - & - & - & - & - & - & - & - & - & - & - \\
\hline Braunvieh & 24 & - & 0.98 & - & - & - & - & - & - & - & - & - & - & 0.02 & - & - & - \\
\hline Brown Swiss & 26 & - & 0.98 & - & - & - & 0.02 & - & - & - & - & - & - & - & - & - & - \\
\hline Charolais & 24 & 0.02 & 0.79 & - & 0.06 & - & - & 0.13 & - & - & - & - & - & - & 0.02 & - & - \\
\hline Chianina & 24 & - & 0.98 & - & - & 0.02 & - & - & - & - & - & - & - & - & - & - & - \\
\hline Corriente & 24 & - & 1.00 & - & - & - & - & - & - & - & - & - & - & - & - & - & - \\
\hline Devon & 23 & - & 0.87 & - & - & 0.04 & 0.09 & - & - & - & - & - & - & - & - & - & - \\
\hline Dexter & 22 & - & 1.00 & - & - & - & - & - & - & - & - & - & - & - & - & - & - \\
\hline Gelbvieh & 23 & - & 0.70 & - & - & - & 0.07 & 0.24 & - & - & - & - & - & - & - & - & - \\
\hline Guernsey & 23 & - & 0.96 & - & - & 0.02 & 0.02 & - & - & - & - & - & - & - & - & - & - \\
\hline
\end{tabular}




\begin{tabular}{|c|c|c|c|c|c|c|c|c|c|c|c|c|c|c|c|c|c|}
\hline \multirow[b]{2}{*}{ Breed group } & \multirow[b]{2}{*}{$\begin{array}{c}\text { Animals } \\
\text { typed } \\
(n=1142)\end{array}$} & \multirow[b]{2}{*}{$\mathbf{C 5}^{\mathrm{b}}$} & \multicolumn{10}{|c|}{ CD18 protein variant allele frequency } & \multirow[b]{2}{*}{$11^{\mathrm{b}}$} & \multirow[b]{2}{*}{12} & \multirow[b]{2}{*}{$13^{b}$} & \multirow[b]{2}{*}{14} & \multirow[b]{2}{*}{$15^{\mathrm{b}}$} \\
\hline & & & 1 & 2 & 3 & 4 & 5 & 6 & 7 & 8 & $9^{\mathrm{b}}$ & $10^{c}$ & & & & & \\
\hline Hereford & 24 & - & 0.98 & - & - & - & - & 0.02 & - & - & - & - & - & - & - & - & - \\
\hline Highland & 24 & - & 1.00 & - & - & - & - & - & - & - & - & - & - & - & - & - & - \\
\hline Holstein & 81 & - & 0.93 & - & - & 0.02 & 0.01 & - & - & - & - & 0.04 & - & - & - & - & - \\
\hline Indu-Brazil & 25 & 0.09 & - & 0.32 & 0.55 & - & 0.02 & - & - & - & 0.06 & - & - & - & 0.02 & 0.02 & - \\
\hline Jersey & 29 & - & 1.00 & - & - & - & - & - & - & - & - & - & - & - & - & - & - \\
\hline Limousin & 24 & - & 0.90 & - & - & 0.10 & - & - & - & - & - & - & - & - & - & - & - \\
\hline Maine-Anjou & 24 & - & 0.96 & - & - & - & - & 0.04 & - & - & - & - & - & - & - & - & - \\
\hline Marchigiana & 24 & - & 1.00 & - & - & - & - & - & - & - & - & - & - & - & - & - & - \\
\hline Mini Hereford & 24 & - & 1.00 & - & - & - & - & - & - & - & - & - & - & - & - & - & - \\
\hline Mini Zebu & 24 & - & 0.33 & 0.15 & 0.48 & - & - & - & - & - & - & - & - & - & - & 0.04 & - \\
\hline Montbeliard & 24 & - & 0.94 & - & - & - & 0.06 & - & - & - & - & - & - & - & - & - & - \\
\hline Murray Gray & 20 & - & 0.78 & - & - & - & 0.23 & - & - & - & - & - & - & - & - & - & - \\
\hline Nelore & 24 & - & - & 0.16 & 0.82 & - & - & - & - & - & - & - & - & - & - & 0.02 & - \\
\hline Piedmontese & 25 & - & 0.92 & - & - & - & 0.08 & - & - & - & - & - & - & - & - & - & - \\
\hline Pinzgauer & 23 & - & 0.89 & - & - & - & 0.11 & - & - & - & - & - & - & - & - & - & - \\
\hline Red Angus & 24 & - & 1.00 & - & - & - & - & - & - & - & - & - & - & - & - & - & - \\
\hline Red Poll & 23 & - & 0.98 & - & - & - & - & 0.02 & - & - & - & - & - & - & - & - & - \\
\hline Romagnola & 24 & - & 1.00 & - & - & - & - & - & - & - & - & - & - & - & - & - & - \\
\hline Salers & 24 & - & 0.77 & - & - & - & - & 0.21 & - & 0.02 & - & - & - & - & - & - & - \\
\hline $\begin{array}{l}\text { Santa } \\
\text { Gertrudis }\end{array}$ & 24 & 0.02 & 0.63 & 0.02 & 0.25 & - & 0.02 & - & - & - & 0.02 & - & - & - & - & 0.06 & - \\
\hline Senepol & 23 & - & 0.89 & 0.04 & - & - & 0.07 & - & - & - & - & - & - & - & - & - & - \\
\hline Shorthorn & 23 & - & 0.96 & - & - & - & 0.04 & - & - & - & - & - & - & - & - & - & - \\
\hline Simmental & 23 & - & 0.87 & - & - & - & 0.09 & 0.04 & - & - & - & - & - & - & - & - & - \\
\hline Tarentaise & 24 & - & 0.94 & - & - & 0.02 & 0.02 & 0.02 & - & - & - & - & - & - & - & - & - \\
\hline $\begin{array}{l}\text { Texas } \\
\text { Longhorn }\end{array}$ & 23 & - & 0.74 & 0.07 & 0.15 & 0.04 & - & - & - & - & - & - & - & - & - & - & - \\
\hline $\begin{array}{l}\text { T. Longhorn, } \\
\text { CTLR }\end{array}$ & 19 & - & 0.95 & - & 0.05 & - & - & - & - & - & - & - & - & - & - & - & - \\
\hline Tuli & 23 & 0.04 & 0.91 & - & 0.04 & - & - & - & - & - & - & - & - & - & - & - & 0.04 \\
\hline Wagyu & 22 & 0.14 & 0.80 & - & - & - & 0.07 & - & - & - & - & - & 0.14 & - & - & - & - \\
\hline
\end{tabular}

${ }^{a}$ CD18 protein variant allele definitions are shown in Table 2. ${ }^{\circ}$ The CD18 C5 missense variant appears in protein variants 9, 11,13 , and $15 .{ }^{\circ}$ The CD18 G128

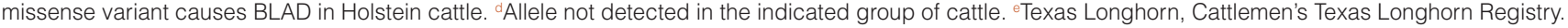

of the Holstein breed (Figure 2). CD18 positions 65, 104, and 155 are also conserved and the variant allele in cattle is rare. Based only on the degree of residue conservation across species, the proposed predicted order of negative impact on CD18 function in cattle was: $\mathrm{G}_{128}>\mathrm{G}_{65}=\mathrm{M}_{104}>\mathrm{P}_{155}$. The $\mathrm{CD} 18 \mathrm{~K}_{27}$ indicine variant was conserved throughout the jawed vertebrates and thus, the major $\mathrm{N}_{27}$ taurine variant was not observed in any other species. However, based on its high frequency in most taurines, the $\mathrm{N}_{27}$ variant does not appear to be deleterious.

The conservation of arginine at positions $3\left(\mathrm{R}_{3}\right)$ and $5\left(\mathrm{R}_{5}\right)$ in CD18 signal peptides was of particular interest because this region binds bacterial Lkt in ruminant species, which includes the Bovids, Cervids, Giraffids, musk deer, chevrotains, and pronghorns. The $\mathrm{R}_{3}$ residue was conserved throughout the Bovinae, but not in sheep and goat, which have proline at that position (Figure 2). The histidine residue at position $3\left(\mathrm{H}_{3}\right)$ was rare in cattle, not observed in other ruminants, and on a distal node of the phylogenetic tree (CD18 polypeptide variant "7", Figure 1C). Two animals from the Brahman breed group were identified with the $\mathrm{H}_{3}$ and one was homozygous, indicating that $\mathrm{H}_{3}$ is not a lethal recessive variant $\left(\mathrm{H}_{3}, \mathrm{H}_{3}\right.$, Extended Data Table $\mathrm{S} 2^{45}$, and $\mathrm{R}_{3}, \mathrm{H}_{3}$, Extended Data Table $\mathrm{S}^{43}$ ). Unlike $\mathrm{R}_{3}$, the $\mathrm{R}_{5}$ variant was not conserved in Bovinae, since eland have cysteine at this site $\left(\mathrm{C}_{5}\right)$. In addition, the $\mathrm{C}_{5}$ variant was present on four distinct putative CD18 polypeptide variants: "9", "11", "13", and "15" (Figure 1C), including both taurine- and indicine-influenced breeds. The presence of the $\mathrm{C}_{5}$ variant on multiple but infrequent haplotypes indicates recombination has occurred between this and other CD18 missense variants.

Comparison of batch production methods of biologicallyactive Lkt with two reference strains of $M$. haemolytica The discovery of missense variants in the CD18 signal peptide provided the opportunity to test these variants using in vitro cell assays with bacterial Lkt. However, producing sufficient and 


\begin{tabular}{|c|c|c|c|c|c|c|c|c|c|c|c|c|c|c|c|c|}
\hline \multirow[b]{2}{*}{ Taxonomic group } & \multirow[b]{2}{*}{$\begin{array}{c}\text { Species } \\
\text { common } \\
\text { name }\end{array}$} & \multirow[b]{2}{*}{$\begin{array}{c}\text { TMRCA } \\
\text { (Ma) }\end{array}$} & \multirow[b]{2}{*}{$\begin{array}{c}\text { Overall } \\
\text { identity } \\
(\%)\end{array}$} & \multicolumn{13}{|c|}{ Position in CD18 } \\
\hline & & & & \multicolumn{5}{|c|}{$\begin{array}{l}\text { Exon Exon Exon } \\
2 \\
\end{array}$} & $\overline{113}$ & \multicolumn{4}{|c|}{$\begin{array}{c}\text { Exon } \\
5\end{array}$} & 155 & $\begin{array}{l}\text { Exon } \\
\frac{10}{392}\end{array}$ & $\begin{array}{l}\text { Exon } \\
\frac{14}{656}\end{array}$ \\
\hline 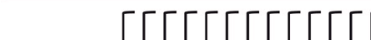 & [ Cattle variant 1 & 0 & 100.0 & $\mathbf{R}$ & $\mathbf{R}$ & $\mathbf{N}$ & $\mathbf{R}$ & $T$ & v & A & $\mathrm{N}$ & $\mathbf{R}$ & D & $\mathbf{R}$ & $\mathbf{Q}$ & $\mathbf{P}$ \\
\hline & Cattle variant 2 & 0 & 99.3 & . & . & K & . & . & A & $S$ & $S$ & $Q$ & . & . & . & \\
\hline & Cattle variant 3 & 0 & 99.9 & . & . & & . & . & . & . & . & . & . & . & . & . \\
\hline & Cattle variant 4 & 0 & 99.9 & . & . & & . & . & . & . & . & . & . & . & K & . \\
\hline & Cattle variant 5 & 0 & 99.9 & . & . & & . & e & . & $\cdot$ & . & . & . & . & . & L \\
\hline & Cattle variant 6 & 0 & 99.9 & . & . & . & . & . & . & . & . & W & . & . & . & . \\
\hline & Cattle variant 7 & 0 & 99.2 & $\mathrm{H}$ & . & & . & . & $A$ & $S$ & $\mathrm{~S}$ & $Q$ & . & . & . & . \\
\hline & Cattle variant 8 & 0 & 99.9 & . & . & . & G & . & . & & . & . & . & . & . & . \\
\hline & Cattle variant 9 & 0 & 99.2 & . & C & $\mathrm{K}$ & . & . & $A$ & $S$ & $S$ & $Q$ & . & . & . & . \\
\hline & Cattle variant 10 & 0 & 99.9 & . & . & . & . & . & . & . & . & . & G & . & . & \\
\hline Bovinae & Cattle variant 11 & 0 & 99.7 & . & C & & . & . & . & . & . & . & . & . & . & L \\
\hline & Cattle variant 12 & 0 & 99.7 & . & . & & . & 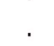 & . & . & . & . & . & $P$ & . & L \\
\hline & Cattle variant 13 & 0 & 99.6 & . & C & $\mathrm{K}$ & . & . & . & . & . & . & . & . & . & . \\
\hline & Cattle variant 14 & 0 & 99.7 & . & . & & . & M & . & . & . & . & . & . & . & . \\
\hline & Cattle variant 15 & 0 & 99.9 & . & C & . & . & . & . & . & . & . & . & . & . & . \\
\hline & Yak & 5 & 99.9 & & . & $\mathrm{K}$ & . & . & . & . & . & . & . & . & . & . \\
\hline & Bison & 5 & 99.2 & . & . & $\mathrm{K}$ & . & . & A & . & $S$ & $Q$ & . & . & . & . \\
\hline & Gaur & 5 & 99.5 & . & . & $\mathrm{K}$ & . & . & . & . & . & . & . & . & . & . \\
\hline & Banteng & 5 & 99.2 & & . & K & . & . & . & V & . & . & . & . & . & . \\
\hline & Water buffalo & 15 & 98.2 & . & . & $\mathrm{K}$ & . & . & A & & . & . & . & . & . & . \\
\hline L & Eland & 17 & 95.8 & . & C & K & . & . & A & V & . & $Q$ & . & . & . & . \\
\hline Bovidae & Sheep & 26 & 95.4 & $P$ & . & $\mathrm{K}$ & . & . & $A$ & . & . & $Q$ & . & . & . & V \\
\hline & Goat & 26 & 96.0 & $P$ & . & $\mathrm{K}$ & . & . & A & . & . & $Q$ & . & . & . & V \\
\hline & Elk & 27 & 95.1 & 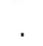 & . & $\mathrm{K}$ & . & . & A & & . & $\hat{Q}$ & . & . & K & . \\
\hline & Dolphin & 56 & 89.7 & . & . & $\mathrm{K}$ & . & . & $A$ & V & . & $Q$ & . & . & K & . \\
\hline Artiodactyla & Orca & 56 & 89.9 & 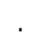 & . & $\mathrm{K}$ & . & . & $A$ & V & . & $Q$ & . & . & K & \\
\hline & Swine & 62 & 88.0 & C & C & $\mathrm{K}$ & . & . & A & _- & . & . & . & . & . & $M$ \\
\hline & Alpaca & 64 & 88.0 & & & $\mathrm{~K}$ & . & . & A & . & $T$ & . & . & . & . & . \\
\hline L & Camel & 64 & 88.0 & $\bar{P}$ & . & $\mathrm{K}$ & . & . & A & . & $\mathrm{T}$ & . & . & . & . & . \\
\hline Laurasiatheria & Horse & 78 & 81.4 & _ & . & G & . & . & A & _- & . & $Q$ & . & $Q$ & $\mathrm{~N}$ & . \\
\hline Laulastanteria & Panda & 78 & 81.9 & . & A & $\mathrm{K}$ & . & . & A & - & . & . & . & . & . & . \\
\hline & Pangolin & 78 & 80.5 & W & $S$ & $\mathrm{~K}$ & . & . & A & $\overline{\mathrm{T}}$ & . & . & . & . & $\mathrm{R}$ & . \\
\hline & Human & 97 & 83.1 & G & . & & . & . & _- & . & . & . & . & . & $\mathrm{H}$ & . \\
\hline & Chimp & 97 & 83.5 & G & . & $\mathrm{K}$ & . & . & - & . & . & . & . & . & $\mathrm{H}$ & . \\
\hline & Gorilla & 97 & 83.0 & $G$ & . & K & . & . & $\bar{A}$ & . & . & . & . & . & $\mathrm{H}$ & . \\
\hline Boreoeutheria & Baboon & 97 & 82.1 & G & . & & . & . & _- & . & $\mathrm{T}$ & . & . & $Q$ & $\mathrm{~L}$ & . \\
\hline & Hampster & 97 & 83.1 & G & $\mathrm{H}$ & $\mathrm{K}$ & . & . & - & - & . & . & . & . & $S$ & . \\
\hline & Rat & 97 & 81.3 & G & $\mathrm{H}$ & $\mathrm{K}$ & . & 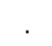 & - & . & . & . & . & $Q$ & $S$ & . \\
\hline & Mouse & 97 & 81.4 & G & . & K & . & . & - & . & . & . & . & $Q$ & $\mathrm{~S}$ & . \\
\hline TheriaL & Opossum & ก 164 & 73.0 & $Y$ & $S$ & $\mathrm{~K}$ & S & $Q$ & $\overline{\mathrm{A}}$ & & . & K & . & . & $S$ & . \\
\hline & Eagle & 310 & 64.4 & . & C & K & M & $\vec{H}$ & A & V & E & . & . & . & I & L \\
\hline Amniota & Chicken & 310 & 63.5 & . & $\mathrm{C}$ & K & I & $\mathrm{H}$ & - & . & $\mathrm{D}$ & . & . & . & $A$ & $\mathrm{R}$ \\
\hline & Alligator & 310 & 63.5 & . & C & $\mathrm{K}$ & I & $\mathrm{N}$ & - & _- & . & $\mathrm{H}$ & . & E & $S$ & L \\
\hline Tetrapoda [ & Frog & 350 & 56.6 & W & $Y$ & K & D & $S$ & - & - & D & . & . & $\mathrm{E}$ & K & $E$ \\
\hline Sarcopteryii L & Coelacanth & 400 & 54.5 & $\mathrm{~L}$ & $Q$ & K & A & $A$ & $\bar{G}$ & $P$ & $S$ & $\mathrm{~K}$ & . & $\bar{Q}$ & K & V \\
\hline Euteleostomi & Fish & 450 & 49.2 & $Q$ & V & K & V & $Q$ & - & $P$ & $Q$ & $\mathrm{~K}$ & . & $\mathrm{E}$ & K & K \\
\hline Gnathostomata & Shark & 483 & 48.8 & M & M & $\mathrm{K}$ & L & $\mathrm{R}$ & $\overline{\mathrm{K}}$ & I & $\mathrm{K}$ & $\mathrm{K}$ & . & $\mathrm{D}$ & V & $T$ \\
\hline Vertebrata & Lamprey & y 631 & 41.7 & $\mathrm{~L}$ & I & $A$ & V & $\mathrm{R}$ & $E$ & $Q$ & . & . & . & . & $\mathrm{R}$ & L \\
\hline Bilateria & Fruit fly & y 847 & 18.7 & $\mathrm{~S}$ & G & $\mathrm{C}$ & L & Y & $\mathrm{Q}$ & $\mathrm{R}$ & $\mathrm{K}$ & . & . & $Q$ & $P$ & $\mathrm{D}$ \\
\hline
\end{tabular}

Figure 2. Evolutionary comparison of CD18 residues at their variant sites in U.S. cattle. Aligned and gapped protein sequences from a representative set of 56 bilateria species were compared (Extended Data Table S4). At variant sites in cattle, the residues were summarized for a representative subset of 35 species. TMRCA, estimated time to most recent common ancestor in millions of years ${ }^{47}$; letters, IUPAC/ IUBMB codes for amino acids; dot, amino acid residues identical to those in cattle "variant 1"; dash, not enough sequence similarity for comparison or missing residue in that peptide region. 
consistent batches of biologically-active Lkt from reference bacterial strains was a challenge with traditional cell culture medium (RPMI). In an effort to overcome this barrier, Lkt production in RPMI was compared with that in a semi-defined bacterial culture medium (SDM2, Methods) with two wild-type $M$. haemolytica strains. The total biological activity of Lkt excreted into SDM2 culture was up to 80-fold greater at its peak than that in RPMI for a given reference strain of $M$. haemolytica (e.g. Strain 183, Figure 3A). In both media, Lkt activity was induced in late log phase as batch cultures made the transition to stationary phase. Although the biological activity quickly diminished as the culture progressed to stationary phase, the total Lkt protein measured by SDS PAGE continued to increase and the level was stable for hours in the culture supernatant (Figure 3B). The Lkt of clarified SDM2 culture supernatants with the highest cytolytic activity (Strain 183, fraction C, Figure 3B) was estimated to be $90 \%$ pure based on gel densitometry imaging of coomassie-stained SDS-PAGE gels. Preparations of similar quality were used for in vitro assays. The cytolytic activity of these toxin preparations was stable at $-80^{\circ} \mathrm{C}$ for more than 2 years.

\section{CD18 signal peptide variant $C_{5}$ has enhanced binding to bacterial Lkt}

Analysis of cattle ITGB2 haplotypes showed that three distinct polypeptide sequences are encoded in the 22-amino acid signal peptide region: the common variant with arginine at positions 3 and $5\left(R_{3} R_{5}\right)$, a rare variant with histidine at position three $\left(\mathrm{H}_{3} \mathrm{R}_{5}\right)$, and second rare variant with cysteine at position $5\left(\mathrm{R}_{3} \mathrm{C}_{5}\right)$. Synthetic 22-mer peptides representing these three, full-length, signal peptides were tested for their ability to bind Lkt. The synthetic peptides were pre-incubated with M. haemolytica Lkt preparations to allow binding, and applied to Lkt-sensitive BL3 cell cultures in vitro (Figure $4 \mathrm{~A}$ ). The common $\mathrm{R}_{3} \mathrm{R}_{5}$ signal peptide was used as a reference since it has a frequency of approximately 0.98 in U.S. cattle, and is predicted to be present on 10 of the full-length $\mathrm{CD} 18$ sequences. The synthetic $\mathrm{R}_{3} \mathrm{R}_{5}$ signal peptide had a IC50 of $17.9 \mu \mathrm{M}$, which represents the concentration of peptide needed to block $50 \%$ of Lkt-induced cytolysis of BL3 cells. The rare $\mathrm{H}_{3} \mathrm{R}_{5}$ signal peptide variant, which is only found on one full-length $\mathrm{CD} 18$ variant (Figure $1 \mathrm{C}$, variant 7), was similar to the reference, with an IC50 of $21.6 \mu \mathrm{M}$. In contrast, the rare $\mathrm{R}_{3} \mathrm{C}_{5}$ signal peptide found on full-length CD18 variants 9, 11, 13, and 15 had an IC50 of $5.9 \mu \mathrm{M}$, which was 3-fold lower that the reference, indicating an increased affinity for Lkt (Figure 4A).

The optimum blocking of Ltk-induced cytotoxicity has been previously reported to occur with the 13-mer peptide corresponding to $\mathrm{CD} 18$ signal peptide residues 5 to $17^{10}$. Thus, we tested the effect of cysteine at position $5\left(\mathrm{C}_{5}\right)$ in this shorter peptide. The synthetic 13-mer $\mathrm{C}_{5}$ peptide was 3.6-fold more effective at blocking Lkt toxicity compared to the $22-$ mer $\mathrm{R}_{3} \mathrm{C}_{5}$ peptide (IC50 of 1.6 and $5.9 \mu \mathrm{M}$, respectively). When compared to the 13-mer reference peptide with arginine at position five $\left(\mathrm{R}_{5}\right)$, the 13-mer $\mathrm{C}_{5}$ peptide was 8-fold better at blocking Lkt-induced cytotoxicity (IC50 13.0 and $1.6 \mu \mathrm{M}$, respectively; Figure 4B). A negative control 13-mer peptide containing randomly assorted amino acids from the reference peptide sequence failed to inhibit Lkt-induced cytolysis, even at the highest concentration tested $(50 \mu \mathrm{M})$, indicating that inhibition of cytolysis was sequence specific (Extended Data File S2) ${ }^{48}$. Together, these results suggest that peptide sequence and length affect Lkt binding.

\section{Synthetic $C_{5}$ variant CD18 signal peptide blocks Lkt-} induced cytolysis of primary bovine cells

The 13-mer $\mathrm{C}_{5}$ synthetic signal peptide containing CD18 residues 5 to 17 were also tested for their ability to inhibit Lktinduced cytolysis of primary cells isolated from cattle. The purpose was to demonstrate that the reduction in cytotoxicity observed with $\mathrm{C}_{5}$ signal peptides was comparable between the immortalized cell line and freshly isolated leukocytes from cattle. Like the BL3 cell line, the animals used as donor were homozygous for CD18 variant "1", and thus have the reference $\left(\mathrm{R}_{3} \mathrm{R}_{5}\right)$ signal peptide. With primary PBMC (Figure 5A) or PMN (Figure 5B), the 13-mer $\mathrm{C}_{5}$ synthetic signal peptide was significantly better at blocking Lkt-induced cytotoxicity compared to the $\mathrm{R}_{5}$ signal peptide (7- and 14-fold respectively) and was similar to that for BL3 cells (8-fold).

Arginine at position $4\left(R_{4}\right)$ in the eland CD18 signal peptide disrupts the enhanced Lkt binding attributed by $\mathrm{C}_{5}$

Some bovid species have CD18 signal peptide sequences that are slightly different from those in cattle (Figure 6A and Table S3). In water buffalo, the 13-mer peptide sequence corresponding to CD18 signal peptide amino acids 5 to 17 differs at position $16\left(\mathrm{~S}_{16}\right)$, while the same region in sheep differs at positions 10 and $12\left(\mathrm{~F}_{10} \mathrm{~S}_{12}\right)$. However, synthetic peptides corresponding to the water buffalo and sheep sequences were similar to the $R_{5}$ reference cattle signal peptide when tested for their ability to bind Lkt and inhibit cytolysis of BL3 cells in vitro. In contrast, the eland signal peptide was variant at three positions in this region compared to cattle $\left(\mathrm{C}_{5} \mathrm{~V}_{8} \mathrm{G}_{16}\right)$, and its 13-mer synthetic signal peptide had a 24-fold decrease in IC50 compared to the reference cattle $R_{5}$ signal peptide and a similar IC50 compared to the reference cattle $\mathrm{C}_{5}$ signal peptide (Figure 6A). However, if the synthetic peptide is expanded to include the eland residue at position 4, the results were different. Eland have an arginine residue at position $4\left(\mathrm{R}_{4}\right)$ where other ruminants have a glutamine $\left(\mathrm{Q}_{4}\right)$. A synthetic 14-mer signal peptide with $\mathrm{R}_{4}$ (i.e., Eland $\mathrm{R}_{4} \mathrm{C}_{5} \mathrm{~V}_{8} \mathrm{G}_{16}$ ) caused a 66 -fold reduction in the ability of the eland signal peptide to bind Lkt compared to the 13-mer $\left(\mathrm{C}_{5} \mathrm{~V}_{8} \mathrm{G}_{16}\right)$ as measured by IC50 (Figure 6B). When $\mathrm{R}_{4}$ was replaced with the $\mathrm{Q}_{4}$ normally found in cattle and other ruminants (i.e. Eland $\mathrm{Q}_{4} \mathrm{C}_{5} \mathrm{~V}_{8} \mathrm{G}_{16}$ versus $\mathrm{R}_{4} \mathrm{C}_{5} \mathrm{~V}_{8} \mathrm{G}_{16}$ ), Lkt binding was restored. Similarly, when $\mathrm{Q}_{4}$ in the cattle signal peptide $\left(\mathrm{Q}_{4} \mathrm{C}_{5}\right)$ was replaced with $\mathrm{R}_{4}\left(\mathrm{R}_{4} \mathrm{C}_{5}\right)$ there was a significant reduction in the ability of this peptide to bind Lkt (5.6-fold increase in IC50). These results suggest that the amino acid position 4 in the signal peptide can affect Lkt binding and that $\mathrm{R}_{4}$ amino acid sequence in eland may disrupt the enhanced Lkt binding conferred by the $\mathrm{C}_{5}$ variant residue.

A truncated CD18 $\mathrm{C}_{5}$ signal peptide has high affinity for Lkt Toxin inhibitors represent a potentially potent class of therapeutics that could protect animals during acute lung infection. Since truncated synthetic $\mathrm{C}_{5}$ signal peptides showed increase 


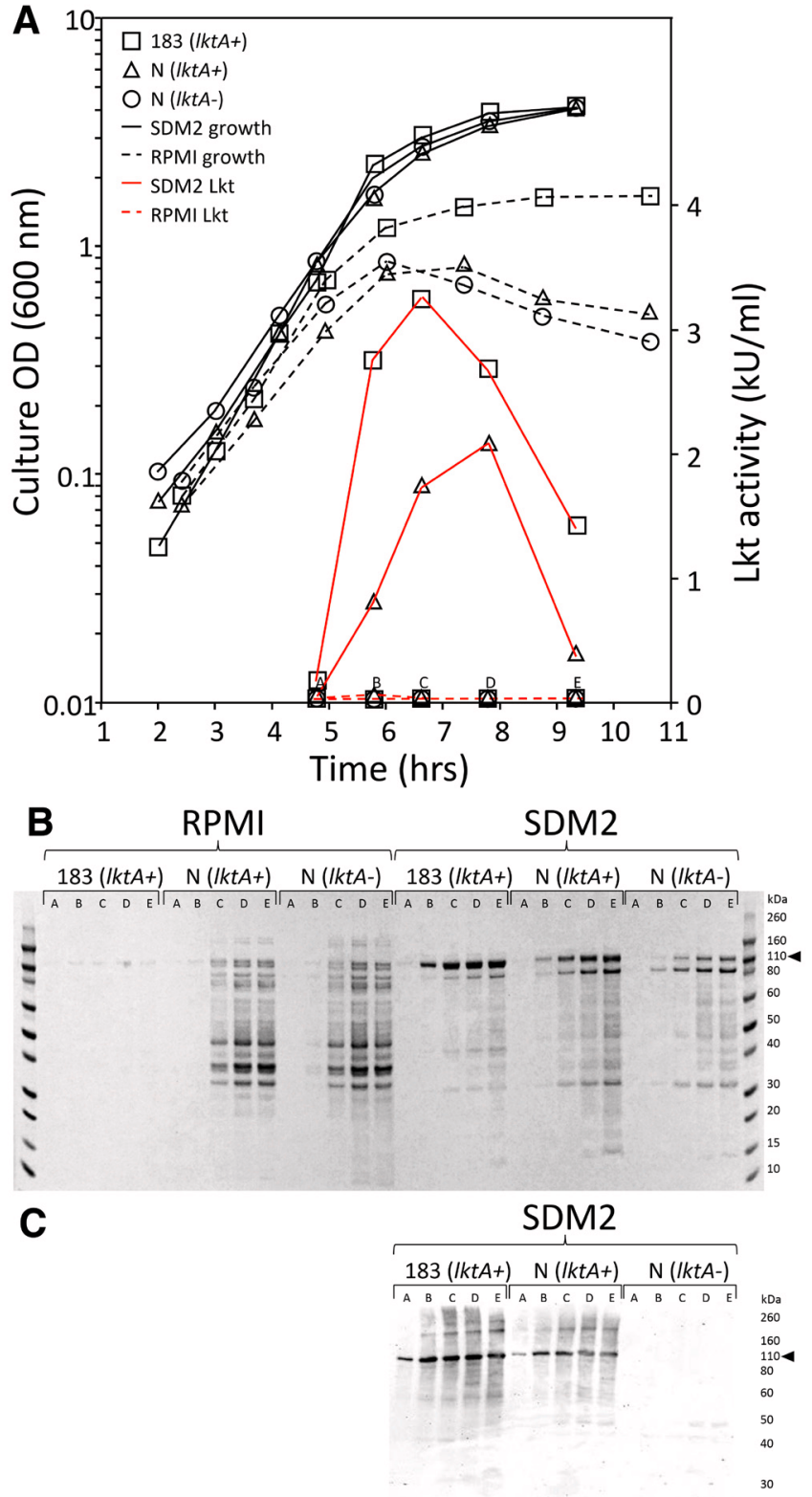

Figure 3. Comparison of M. haemolytica leukotoxin (Lkt) production in cell culture medium and a semi-defined bacterial culture broth. (A) Growth curves of M. haemolytica strains (black lines) and the cytolytic activity of their secreted Lkt (red lines). The strain abbreviations: 183 (ItkA+), USDA-ARS-USMARC-183 $($ ItkA+); N (ltkA+), 89010807N (IktA+); and N (ItkA-), 89010807N (IktA-). Clarified culture supernatants were collected at time points indicated on the $\mathrm{x}$-axis as A through $\mathrm{E}$. (B) Coomassie-stained SDSPAGE of proteins from $50 \mu \mathrm{l}$ each of clarified culture supernatants. (C) Western blot of SDS-PAGE from the same clarified SDM2 culture supernatants that were used in panel (B). The black arrow indicates the expected position of Lkt on SDS-PAGE.

affinity for Lkt, various peptide lengths were tested to identify those with maximum Lkt binding. Removing the first four $\mathrm{N}$-terminal amino acids (MLRQ) resulted in no significant difference in Lkt binding for the $\mathrm{C}_{5}$ or reference $\mathrm{R}_{5}$ signal peptides
A.
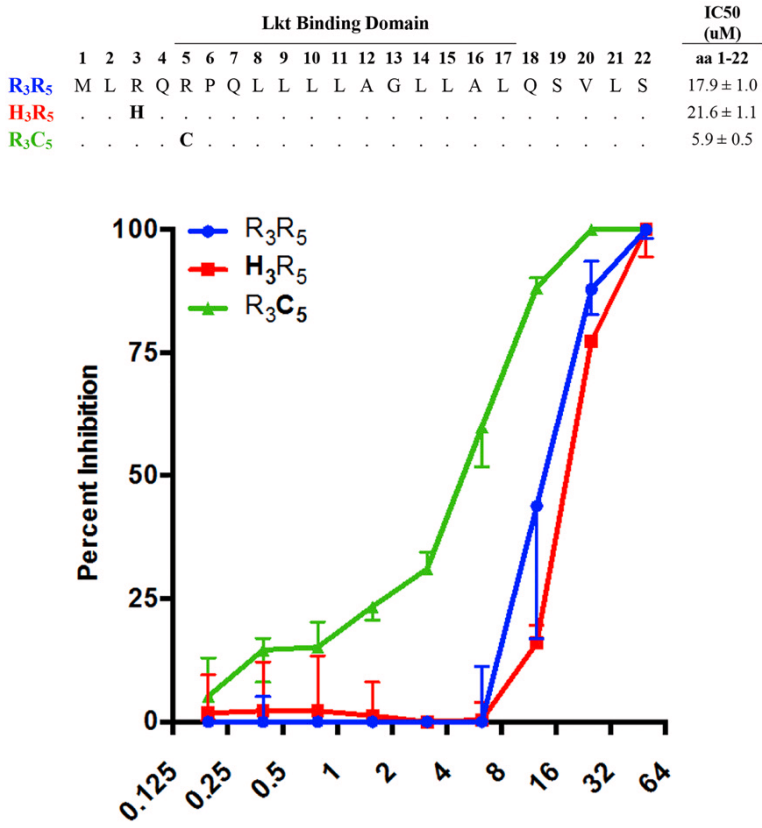

Peptide Dose (uM)

B.

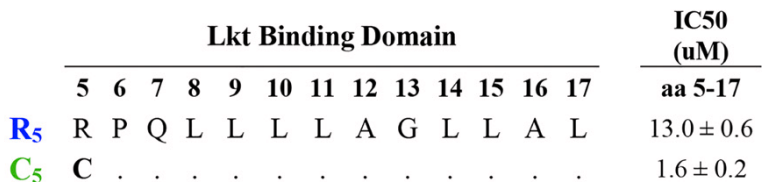

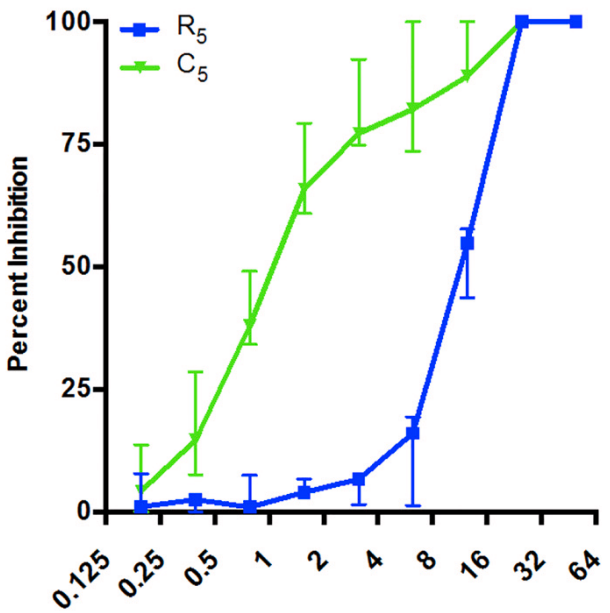

Peptide Dose $(\mu \mathrm{M})$

Figure 4. Cattle CD18 signal peptide variants differentially inhibit leukotoxin (Lkt)-induced cytolysis of bovine BL3 cells. CD18 signal peptide variants were tested for their ability to bind Lkt and inhibit Lkt-induced cytolysis of immortalized bovine BL3 cells using a MTT dye reduction assay. CD18 peptide variants representing amino acids 1 to $22(\mathbf{A})$ or 5 to 17 (B) were tested using 2 -fold serial dilutions at concentrations ranging from $50 \mu \mathrm{M}$ to 0.195 $\mu \mathrm{M}$. Half-maximal inhibitory concentration (IC50) for each peptide was determined using non-linear regression analyses. Data are expressed as the mean with standard deviation $(n=3)$. 

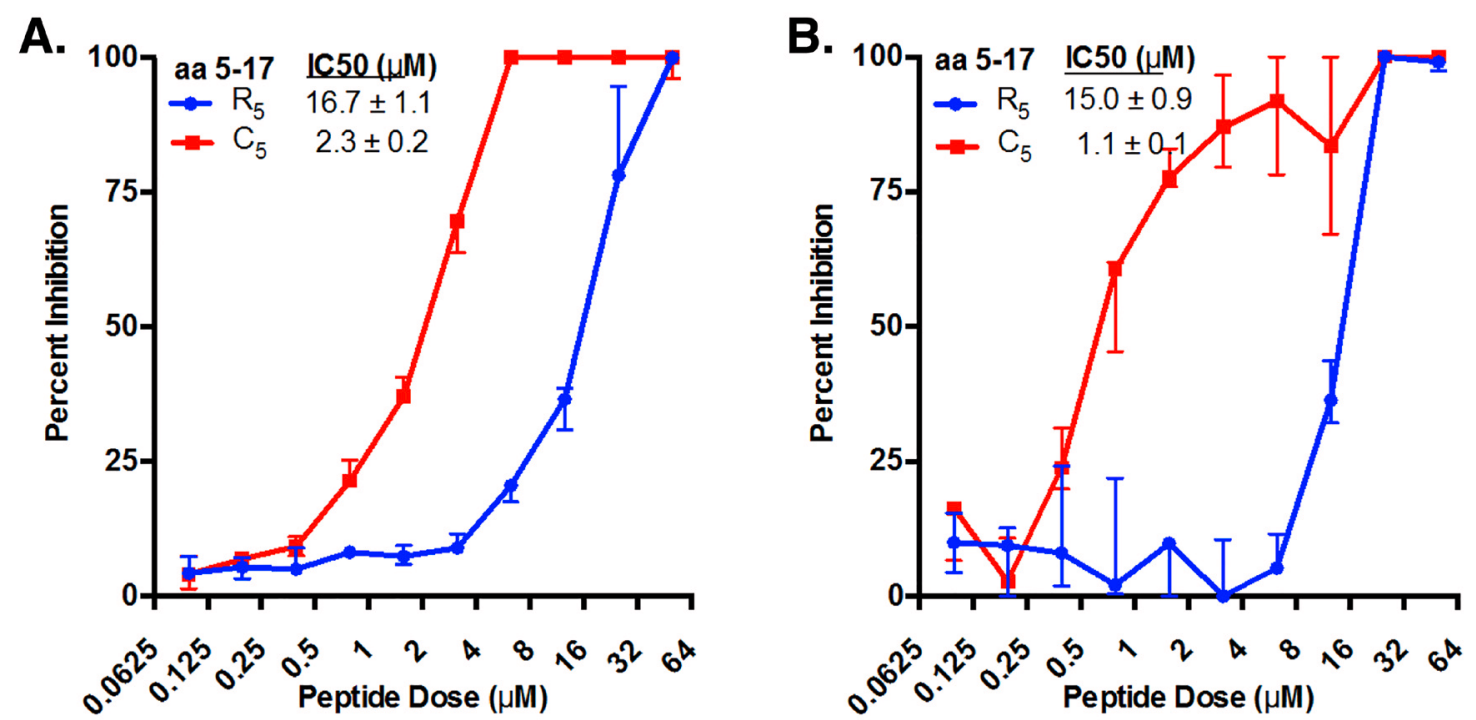

Figure 5. Cattle CD18 signal peptides inhibit leukotoxin (Lkt)-induced cytolysis of primary bovine cells. The 13-mer synthetic signal peptides (from Figure 1B) containing cattle CD18 residues 5 to 17 were tested for their ability to inhibit Lkt-induced cytolysis of primary bovine peripheral blood mononuclear cells (PBMC) $(\mathbf{A})$ and polymorphonuclear leukocytes (PMN) (B). Donor animals were genotyped at the CD18 locus and were homozygous for CD18 variant "1". Peptides were tested using 2 -fold dilutions at concentrations ranging from $50 \mu \mathrm{M}$ to $0.098 \mu \mathrm{M}$. The half-maximal inhibitory concentration (IC50) for each peptide was determined using non-linear regression analyses. Data are expressed as the mean with standard deviation $(n=3)$.

(Extended Data Figure S2) ${ }^{42}$. In contrast, stepwise deletions of C-terminal residues of the $\mathrm{C}_{5}$ signal peptide had a significant impact on Lkt binding with the highest affinity being a $12-$ mer $\mathrm{C}_{5}$ signal peptide with amino acids 5 to 16 . The IC50 of this $12-$ mer $\mathrm{C}_{5}$ peptide (CPQLLLLAGLLA) was 23-fold lower than the 13-mer reference $R_{5}$ signal peptide (residues 5 to 17) and 30-fold lower than the 12-mer $\mathrm{R}_{5}$ signal peptide. Thus, the 12-mer $\mathrm{C}_{5}$ peptide (CPQLLLLAGLLA) represents the minimal naturally-occurring peptide sequence with maximal inhibition of Lkt-induced BL3 cell lysis (Figure 7).

\section{Discussion}

The present report describes bovine CD18 amino acid sequence differences encoded by ITGB2 in 46 breeds of beef and dairy cattle. All of the protein coding variants discovered were missense mutations and their haplotypes were predicted to encode 15

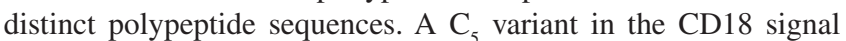
peptide region was shown to cause increased binding to $M$. haemolytica Lkt, a secreted toxin that causes cell lysis and acute inflammation leading to lung injury characteristic of bovine respiratory disease. The $\mathrm{C}_{5}$ signal peptide variant increased the affinity for Lkt, and this effect was influenced by variation at adjacent residues. The increased Lkt binding and protection from cytotoxic effects were observed in the immortalized BL3 cell line, and freshly isolated PBMC and PMN from beef cattle.

The identification of naturally-occurring CD18 variants with increased binding to Lkt has important potential implications for animal health. For example, cattle with the CD18 $\mathrm{C}_{5}$ signal peptide variant may be at increased risk for toxin-related respiratory disease. However, despite the fact that the $\mathrm{C}_{5}$ variant was found in four predicted protein variants in taurine and indicine cattle, its overall frequency in the U.S. cattle population in still very low (0.01). Thus, identifying available homozygous cattle for testing their leukocytes ex vivo for altered Lkt sensitivity will be challenging. Determining whether this altered binding phenotype contributes to differences in lung lesion severity or disease outcome following $M$. haemolytica infection will also be difficult. Together, these factors suggest that identifying and removing animals with the $\mathrm{CD}_{18} \mathrm{C}_{5}$ signal peptide would be premature and unwarranted for most cattle operations at this time.

Recent examples of gene editing in animals have shown that this can be a successful strategy for creating novel host genetic resistance. Groundbreaking work with porcine reproductive and respiratory syndrome virus (PRRSV) has shown that gene editing of a critical entry factor (CD163) confers complete resistance to infection in pigs $^{49,50}$. Similarly, genetic resistance to $M$. haemolytica Lkt has been demonstrated in leukocytes isolated from a homozygous, gene-edited, bovine fetus expressing a cleavable CD18 signal peptide ${ }^{15}$. However, the uncleaved CD18 signal peptide is universally conserved in ruminants and thus, its removal may have deleterious effects on the animal. CD18 forms heterodimers with distinct, but structurally homologous alpha integrin subunits (e.g., CD11a/CD18, CD11b/CD18, and $\mathrm{CD} 11 \mathrm{c} / \mathrm{CD} 18)$, and thus the effect of a cleaved signal peptide may have unknown, but far-reaching effects on biological functions. To date there are no reports of a healthy, live calf expressing a cleavable CD18 signal peptide. Thus, modifying the 
A.

B.

Cattle $\mathrm{Q}_{4} \mathrm{R}_{5}$

Cattle $\mathrm{Q}_{4} \mathrm{C}_{5}$

Cattle $\mathrm{R}_{4} \mathrm{C}_{5}$

Eland $\mathrm{R}_{4} \mathrm{C}_{5} \mathrm{~V}_{8} \mathrm{G}_{16}$

Eland $\mathrm{Q}_{4} \mathrm{C}_{5} \mathrm{~V}_{8} \mathrm{G}_{16}$

Peptide Dose $(\mu \mathrm{M})$
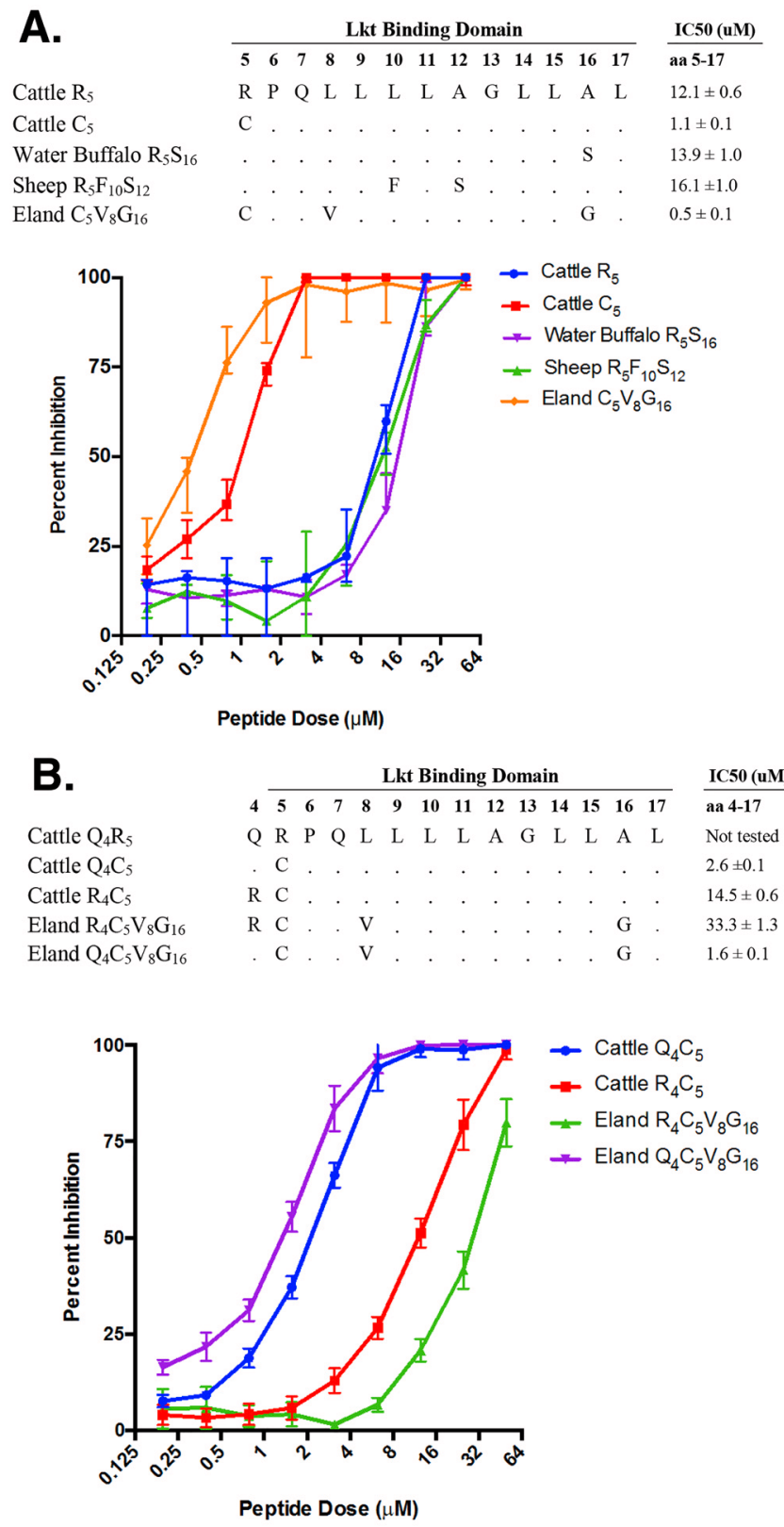

Figure 6. CD18 signal peptides from related mammalian species differentially inhibit leukotoxin (Lkt)-induced cytolysis of bovine BL3 cells. (A) Synthetic 13-mer signal peptides representing amino acids 5 to 17 of sheep, water buffalo, and eland were compared to cattle variants $R_{5}$ and $C_{5}$ for their ability to inhibit Lkt-induced cytolysis of bovine BL3 cells. Peptides were tested using 2-fold dilutions at concentrations ranging from $50 \mu \mathrm{M}$ to $0.195 \mu \mathrm{M}$. (B) Synthetic 14-mer signal peptides representing CD18 amino acids 4 to 17 from eland and cattle variant $C_{5}$ were tested for their ability to bind Lkt. In addition, eland CD18 signal peptides were synthesized where the amino acid at position 4 in eland (arginine, R) was replaced with the amino acid normally found in cattle at this position (glutamine, $\mathrm{Q}$; Eland $\mathrm{Q}_{4} \mathrm{C}_{5} \mathrm{~V}_{8} \mathrm{G}_{16}$ ). Similarly, cattle variant $\mathrm{C}_{5}$ peptides were synthesized where the amino acid at position 4 in cattle was replaced with the amino acid naturally encoded in eland (Cattle $\mathrm{R}_{4} \mathrm{C}_{5}$ ). The half-maximal inhibitory concentration (IC50) for each peptide was determined using non-linear regression analyses. Data are expressed as the mean with standard deviation ( $n=3$ or 4 ).

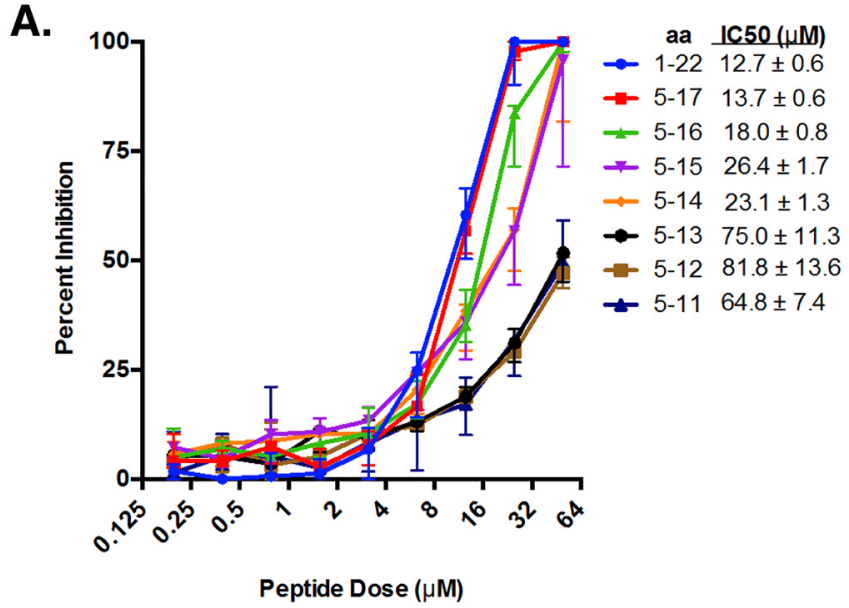

B.

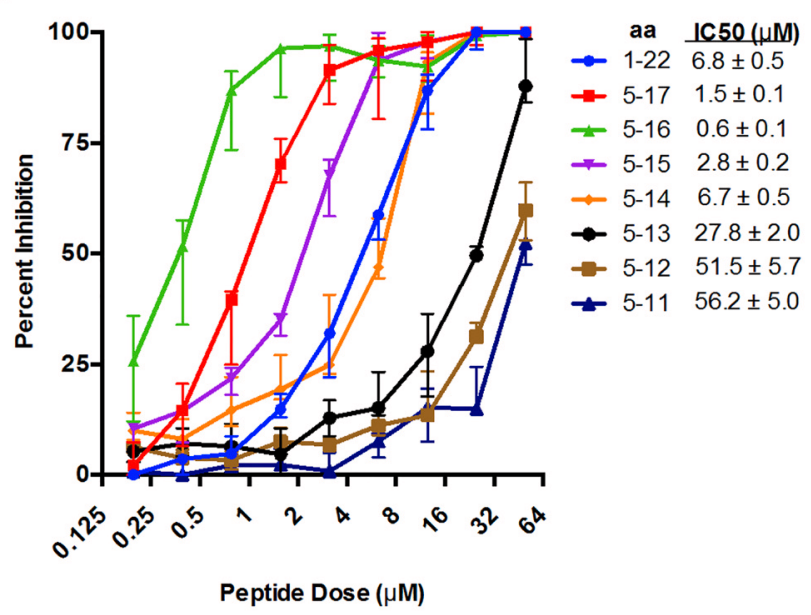

Figure 7. C-terminal truncations reveal the minimal peptide sequence for inhibition of leukotoxin (Lkt)-induced cytolysis. Synthetic CD18 signal peptides were synthesized with single amino acid C-terminal deletions. These peptides were tested for their ability to inhibit Lkt-induced cytolysis of bovine BL3 cells. Peptides were tested at concentrations ranging from $50 \mu \mathrm{M}$ to $0.195 \mu \mathrm{M}$. The half-maximal inhibitory concentration (IC50) for each peptide was determined using non-linear regression analyses. Data are expressed as the mean with standard deviation $(n=3)$.

amino acid sequence of an uncleaved ruminant CD18 signal peptide may be useful as an alternative strategy to reduce Lkt binding, while preserving its normal evolutionarily conserved cellular function.

Identifying the naturally-ocurring CD18 signal peptide residues that influence Lkt binding provides a guide for more extensive analyses that may inform gene edits. Previously, synthetic signal peptides containing the $R_{5}$ residue were used to identify a 13-amino acid minimum CD18 binding site for Lkt (spanning residues 5 through $\left.17,{ }^{10}\right)$. Using synthetic peptides representing cattle $\mathrm{Q}_{4} \mathrm{C}_{5}$ and eland $\mathrm{R}_{4} \mathrm{C}_{5}$, we showed that residues in position 4 can drastically affect Lkt binding and that the net charge 
of the signal peptide is important. The positively charged side chain of $\mathrm{R}_{4}$ apparently disrupts the enhanced binding of $\mathrm{C}_{5}$ signal peptides compared to the neutral side chain of $\mathrm{Q}_{4}$. In addition, the most common CD18 22-mer signal peptide $\left(R_{3} R_{5}\right)$ and the rare $\mathrm{H}_{3} \mathrm{R}_{5}$ signal peptide have a net charge of +2 and reduced Lkt binding compared the $\mathrm{R}_{3} \mathrm{C}_{5}$ peptide (net charge of +1 ). It would be of interest to determine whether increasing the signal peptide net charge to +3 by introducing another positively charged residue could further reduce Lkt binding. However, there are numerous combinatorial peptide possibilities that could lead to a significantly reduced affinity of CD18 for Lkt, while only a few may preserve the basic biological functions of the signal peptide. Although large-scale screening of candidate peptides in vitro and testing them in vivo is beyond the scope of this study, our results suggest this as a possible future avenue of research.

An alternative strategy for reducing the impact of Lkt would be to block its activity in vivo with synthetic CD18 "decoy" peptides such as the 12-mer $\mathrm{C}_{5}$ signal peptide identified here. A similar strategy has been used to neutralize anthrax toxin from Bacillus anthracis (reviewed in 51). A synthetic 12-mer peptide antitoxin, attached to liposome scaffolds in multiple copies, protected host cells from cytotoxicity in vitro and protected rats from becoming moribund in vivo ${ }^{52}$. Although the feasibility of delivering decoy peptides is unknown in cattle, it could be used to neutralize Lkt, and thus protect calves from the major virulence factor associated with lung pathology in bovine respiratory disease complex. One can further imagine combining decoy peptide technology with gene editing to have alveolar leukocytes secrete decoy peptide inhibitors of Lkt at the sites of M. haemolytica infection. Although the theoretical possibilities of using antitoxin and gene editing strategies may be vast, the feasibility of these technologies are still relatively unknown. A better understanding of the underlying molecular mechanisms involved, together with significant improvements in livestock gene editing and decoy peptide technologies, are needed to move the field forward.

\section{Conclusion}

There are more than a dozen missense variants in the CD18 polypeptide, including a $\mathrm{C}_{5}$ variant in the signal peptide that affects Lkt binding. Results in vitro suggest that animals carrying the $\mathrm{C}_{5}$ allele may be more susceptible to the effects of Lkt. These results also identify a potentially potent class of non-antibiotic Lkt inhibitors that could protect cattle from cytotoxic effects during acute lung infections.

\section{Data availability}

Underlying data

Whole genome sequence files (FASTQ) for the BL3 cell line are available in the NCBI SRA under accession number SRX4645762.

The BL3 sequence data have also been deposited with links to BioProject accession number PRJNA325058 (BioSample SAMN05217649) in the NCBI BioProject database.

In addition, access to the aligned sequences is available via the USDA internet site: https://www.ars.usda.gov/plains-area/claycenter-ne/marc/wgs/celllines/ as described in the Methods.

\section{Extended data}

Table S1. MALDI-TOF MS assay design for 14 ITGB2 missense SNPs. DOI: https://doi.org/10.6084/m9.figshare.7449374.v1 ${ }^{53}$.

Table S2. ITGB2 genotypes recorded manually from WGS reads mapped to UMDv3.1 assembly for the USMARC Beef Cattle Diversity Panel v2.9. DOI: https://doi.org/10.6084/ m9.figshare.7449989.v1 $1^{45}$.

Table S3. Haplotype-phased genotypes (diplotypes) for ITGB2 from MALDI-TOF MS assays for 1142 cattle. DOI: https://doi. org/10.6084/m9.figshare.7450673.v1 ${ }^{43}$.

Table S4. Alignment of CD18 sequences from Bilateria species. DOI: https://doi.org/10.6084/m9.figshare.7450796.v144.

Figure S1. Screen image of Integrated Genome Viewer software displaying ITGB2 N27KI genotype data for eight bulls. DOI: https://doi.org/10.6084/m9.figshare.7450814.v1 ${ }^{35}$.

Figure S2. Effect of N-terminal truncations of synthetic CD18 signal peptides on Lkt binding. Synthetic CD18 signal peptides were synthesized with four amino acids removed from $\mathrm{N}$-terminus (MLRQ). The common $\mathrm{R}_{3} \mathrm{R}_{5}(\mathrm{~A})$ or the rare $\mathrm{R}_{3} \mathrm{C}_{5}$ variant (B) signal peptides were tested for their ability to inhibit leukotoxin-induced cytolysis of bovine BL3 cells using a MTT cytotoxicity assay. Peptides were tested at concentrations ranging from $50 \mu \mathrm{M}$ to 0.195 $\mu \mathrm{M}$. Data are expressed as the mean with standard deviation $(n=3)$. DOI: https://doi.org/10.6084/m9.figshare.7450823.v1 $1^{42}$.

File S1. VCF file with SNPs from BL3 WGS aligned to the bovine UMD3.1 reference assembly. https://doi.org/10.6084/ m9.figshare.7450826.v1 $1^{32}$.

File S2. MTT dye-reduction cytotoxicity assay results. Percent inhibition of cytotoxicity was calculated as described in the Methods. Shown are the results used for statistical analyses of data and for generating Figure 1-Figure 3, Figure 7. DOI: https:// doi.org/10.6084/m9.figshare.745103948.

Grant information

Funding for this research was provided by the USDA, ARS appropriated projects 5438-32000-029-00D (CGCM) and 5438-31320012-00D (TPLS).

The funders had no role in study design, data collection and analysis, decision to publish, or preparation of the manuscript.

\section{Acknowledgements}

The authors thank Brad Sharp, Stacy Bierman, and Jacky Carnahan for technical support and Stephanie Schmidt for secretarial support. The use of product and company names is necessary to accurately report the methods and results; however, the United States Department of Agriculture (USDA) neither guarantees nor warrants the standard of the products. The use of names by the USDA implies no approval of the product to the exclusion of others that may also be suitable. The USDA is an equal opportunity provider and employer. 
1. Griffin D: Bovine pasteurellosis and other bacterial infections of the respiratory tract. Vet Clin North Am Food Anim Pract. 2010; 26(1): 57-71, table of contents. PubMed Abstract | Publisher Full Text

2. Whiteley LO, Maheswaran SK, Weiss DJ, et al.: Pasteurella haemolytica A1 and bovine respiratory disease: pathogenesis. J Vet Intern Med. 1992; 6(1): 11-22. PubMed Abstract | Publisher Full Text

3. Frank GH, Smith PC: Prevalence of Pasteurella haemolytica in transported calves. Am J Vet Res. 1983; 44(6): 981-5. PubMed Abstract

4. Angen O, Thomsen J, Larsen LE, et al: Respiratory disease in calves: microbiological investigations on trans-tracheally aspirated bronchoalveolar fluid and acute phase protein response. Vet Microbiol. 2009; 137(1-2): 165-71. PubMed Abstract | Publisher Full Text

5. Griffin D, Chengappa MM, Kuszak J, et al: Bacterial pathogens of the bovine respiratory disease complex. Vet Clin North Am Food Anim Pract. 2010; 26(2): 381-94.

PubMed Abstract | Publisher Full Text

6. Singh K, Ritchey JW, Confer AW: Mannheimia haemolytica: bacterial-host interactions in bovine pneumonia. Vet Pathol. 2011; 48(2): 338-48. PubMed Abstract | Publisher Full Text

7. Highlander SK, Fedorova ND, Dusek DM, et al.: Inactivation of Pasteurella (Mannheimia) haemolytica leukotoxin causes partial attenuation of virulence in a calf challenge model. Infect Immun. 2000; 68(7): 3916-22. PubMed Abstract | Publisher Full Text | Free Full Text

8. Tatum FM, Briggs RE, Sreevatsan SS, et al.: Construction of an isogenic leukotoxin deletion mutant of Pasteurella haemolytica serotype 1: characterization and virulence. Microb Pathog. 1998; 24(1): 37-46. PubMed Abstract | Publisher Full Text

9. Ackermann MR, Brogden KA: Response of the ruminant respiratory tract to Mannheimia (Pasteurella) haemolytica. Microbes Infect. 2000; 2(9): 1079-88. PubMed Abstract | Publisher Full Text

10. Shanthalingam S, Srikumaran S: Intact signal peptide of CD18, the beta-subunit of beta ${ }_{2}$-integrins, renders ruminants susceptible to Mannheimia haemolytica leukotoxin. Proc Natl Acad Sci U S A. 2009; 106(36): 15448-53. PubMed Abstract | Publisher Full Text | Free Full Text

11. Dassanayake RP, Maheswaran SK, Srikumaran S: Monomeric expression of bovine beta $_{2}$-integrin subunits reveals their role in Mannheimia haemolytica leukotoxin-induced biological effects. Infect Immun. 2007; 75(10): 5004-10. PubMed Abstract | Publisher Full Text | Free Full Text

12. Deshpande MS, Ambagala TC, Ambagala AP, et al.: Bovine CD18 is necessary and sufficient to mediate Mannheimia (Pasteurella) haemolytica leukotoxininduced cytolysis. Infect Immun. 2002; 70(9): 5058-64. PubMed Abstract | Publisher Full Text | Free Full Text

13. Jeyaseelan S, Sreevatsan S, Maheswaran SK: Role of Mannheimia haemolytica leukotoxin in the pathogenesis of bovine pneumonic pasteurellosis. Anim Health Res Rev. 2002; 3(2): 69-82. PubMed Abstract | Publisher Full Text

14. Slocombe RF, Malark J, Ingersoll R, et al.: Importance of neutrophils in the pathogenesis of acute pneumonic pasteurellosis in calves. Am J Vet Res. 1985; 46(11): 2253-8. PubMed Abstract

15. Shanthalingam S, Tibary A, Beever JE, et al.: Precise gene editing paves the way for derivation of Mannheimia haemolytica leukotoxin-resistant cattle. Proc Natt Acad Sci U S A. 2016; 113(46): 13186-13190. PubMed Abstract | Publisher Full Text | Free Full Text

16. Shuster DE, Bosworth BT, Kehrli ME Jr: Sequence of the bovine CD18-encoding cDNA: comparison with the human and murine glycoproteins. Gene. 1992; 114(2): $267-71$

PubMed Abstract | Publisher Full Text

17. Shuster DE, Kehrli ME Jr, Ackermann MR, et al:: Identification and prevalence of a genetic defect that causes leukocyte adhesion deficiency in Holstein cattle. a genetic defect that causes leukocyte adhesion
Proc Natl Acad Sci U S A. 1992; 89(19): 9225-9. PubMed Abstract | Publisher Full Text | Free Full Text

18. Jeyaseelan S, Hsuan SL, Kannan MS, et al:: Lymphocyte function-associated antigen 1 is a receptor for Pasteurella haemolytica leukotoxin in bovine leukocytes. Infect Immun. 2000; 68(1): 72-9. PubMed Abstract | Publisher Full Text | Free Full Text

19. Ackermann MR, Kehrli ME Jr, Hawkins HK, et al: Identification of beta integrins in bovine neutrophils by scanning electron microscopy in the backscatter mode and transmission electron microscopy. Vet Pathol. 1993; 30(3): 296-8. PubMed Abstract | Publisher Full Text

20. Heaton MP, Smith TP, Carnahan JK, et al: Using diverse U.S. beef cattle genomes to identify missense mutations in EPAS1, a gene associated with pulmonary hypertension [version 2; referees: 2 approved]. F1000Res. 2016; 5: 2003. PubMed Abstract | Publisher Full Text | Free Full Text

21. Heaton MP, Chitko-McKnown CG, Grosse WM, et al:: Interleukin-8 haplotype structure from nucleotide sequence variation in commercial populations of U.S. beef cattle. Mamm Genome. 2001; 12(3): 219-26. PubMed Abstract | Publisher Full Text

22. Heaton MP, Keele JW, Harhay GP, et al:: Prevalence of the prion protein gene
E211K variant in U.S. cattle. BMC Vet Res. 2008; 4: 25 PubMed Abstract | Publisher Full Text | Free Full Text

23. Heaton MP, Grosse WM, Kappes SM, et al: Estimation of DNA sequence diversity in bovine cytokine genes. Mamm Genome. 2001; 12(1): 32-7. PubMed Abstract | Publisher Full Text

24. Nickerson DA, Tobe VO, Taylor SL: PolyPhred: automating the detection and genotyping of single nucleotide substitutions using fluorescence-based resequencing. Nucleic Acids Res. 1997; 25(14): 2745-51. PubMed Abstract | Publisher Full Text | Free Full Text

25. Ewing B, Green P: Base-calling of automated sequencer traces using phred. II. Error probabilities. Genome Res. 1998; 8(3): 186-94. PubMed Abstract | Publisher Full Text

26. Ewing B, Hillier L, Wendl MC, et al.: Base-calling of automated sequencer traces using phred. I. Accuracy assessment. Genome Res. 1998; 8(3): 175-85. PubMed Abstract | Publisher Full Text

27. Gordon D, Abajian C, Green P: Consed: a graphical tool for sequence finishing. Genome Res. 1998; 8(3): 195-202. PubMed Abstract | Publisher Full Text

28. Zimin AV, Delcher AL, Florea L, et al:: A whole-genome assembly of the domestic cow, Bos taurus. Genome Biol. 2009; 10(4): R42. PubMed Abstract | Publisher Full Text | Free Full Text

29. Li H, Durbin R: Fast and accurate long-read alignment with Burrows-Wheeler transform. Bioinformatics. 2010; 26(5): 589-95.

PubMed Abstract | Publisher Full Text | Free Full Text

30. Li H, Handsaker B, Wysoker A, et al.: The Sequence Alignment/Map format and SAMtools. Bioinformatics. 2009; 25(16): 2078-9.

PubMed Abstract | Publisher Full Text | Free Full Text

31. McKenna A, Hanna M, Banks E, et al:: The Genome Analysis Toolkit: a MapReduce framework for analyzing next-generation DNA sequencing data. Genome Res. 2010; 20(9): 1297-303. PubMed Abstract | Publisher Full Text | Free Full Text

32. Workman A, Heaton M: File S1.VCF file with SNPs from BL3 WGS aligned to the bovine UMD3.1 reference assembly. figshare. Fileset. 2018.

33. Robinson JT, Thorvaldsdottir $\mathrm{H}$, Winckler $\mathrm{W}$, et al:: Integrative genomics viewer. Nat Biotechnol. 2011; 29(1): 24-6.

PubMed Abstract | Publisher Full Text | Free Full Text

34. Thorvaldsdottir H, Robinson JT, Mesirov JP: Integrative Genomics Viewer (IGV): high-performance genomics data visualization and exploration. Brief Bioinform. 2013; 14(2): 178-92.

PubMed Abstract | Publisher Full Text | Free Full Text

35. Workman A, Heaton M: Figure S1. Screen image of Integrated Genome Viewer (IGV) software displaying ITGB2 N27KI genotype data for eight bulls. figshare. Figure. 2018.

36. Heaton MP, Harhay GP, Smith TP, et al:: Complete Closed Genome Sequences of a Mannheimia haemolytica Serotype A1 Leukotoxin Deletion Mutant and Its Wild-Type Parent Strain. Genome Announc. 2015; 3(3): pii: e00417-15. PubMed Abstract | Publisher Full Text | Free Full Text

37. Murphy GL, Whitworth LC, Clinkenbeard KD, et al.: Hemolytic activity of the Pasteurella haemolytica leukotoxin. Infect Immun. 1995; 63(8): 3209-12. PubMed Abstract | Free Full Text

38. Harhay GP, Koren S, Phillippy AM, et al:: Complete Closed Genome Sequences of Mannheimia haemolytica Serotypes A1 and A6, Isolated from Cattle. Genome Announc. 2013; 1(3): pii: e00188-13. PubMed Abstract | Publisher Full Text | Free Full Text

39. van Rensburg E, du Preez JC: Effect of $\mathrm{pH}$, temperature and nutrient limitations on growth and leukotoxin production by Mannheimia haemolytica in batch and continuous culture. J Appl Microbiol. 2007; 102(5): 1273-82. PubMed Abstract | Publisher Full Text

40. Schneider CA, Rasband WS, Eliceiri KW: NIH Image to ImageJ: 25 years of image analysis. Nat Methods. 2012; 9(7): 671-5. PubMed Abstract | Publisher Full Text | Free Full Text

41. Chitko-McKown CG, Fox JM, Miller LC, et al:: Gene expression profiling of bovine macrophages in response to Escherichia coli 0157:H7 lipopolysaccharide. Dev Comp Immunol. 2004; 28(6): 635-45. PubMed Abstract | Publisher Full Text

42. Workman A, Heaton M: Figure S2. Effect of N-terminal truncations of synthetic CD18 signal peptides on Lkt binding. figshare. Figure. 2018.

43. Workman A, Heaton M: Table S3. Haplotype-phased genotypes (diplotypes) for ITGB2 from MALDI-TOF MS assays for 1142 cattle. figshare. Dataset. 2018

44. Workman A, Heaton M: Table S4. Alignment of CD18 sequences from Bilateria species. figshare. Dataset. 2018.

45. Workman A, Heaton M: Table S2. ITGB2 genotypes recorded manually from WGS reads mapped to UMDv3.1 assembly for the USMARC Beef Cattle Diversity Panel v2.9. figshare. Dataset. 2018.

46. Nomenclature for incompletely specified bases in nucleic acid sequences. Recommendations 1984. Nomenclature Committee of the International Union of Biochemistry (NC-IUB). Proc Natl Acad Sci U S A. 1986; 83(1): 4-8. PubMed Abstract | Publisher Full Text | Free Full Text 
47. Hedges SB, Marin J, Suleski M, et al:: Tree of life reveals clock-like speciation and diversification. Mol Biol Evol. 2015; 32(4): 835-45 PubMed Abstract | Publisher Full Text | Free Full Text

48. Workman A, Heaton M: File S1. VCF file with SNPs from BL3 WGS aligned to the bovine UMD3.1 reference assembly. figshare. Fileset. 2018.

49. Burkard C, Lillico SG, Reid E, et al:: Precision engineering for PRRSV resistance in pigs: Macrophages from genome edited pigs lacking CD163 SRCR5 domain are fully resistant to both PRRSV genotypes while maintaining biological function. PLoS Pathog. 2017; 13(2): 1006206

PubMed Abstract | Publisher Full Text | Free Full Text

50. Whitworth KM, Rowland RR, Ewen CL, et al:: Gene-edited pigs are protected from porcine reproductive and respiratory syndrome virus. Nat Biotechnol. 2016; 34(1): 20-2

PubMed Abstract | Publisher Full Text

51. Nestorovich EM, Bezrukov SM: Designing inhibitors of anthrax toxin. Expert Opin Drug Discov. 2014; 9(3): 299-318.

PubMed Abstract | Publisher Full Text | Free Full Text

52. Basha S, Rai P, Poon V, et al.: Polyvalent inhibitors of anthrax toxin that target host receptors. Proc Natl Acad Sci U S A. 2006; 103(36): 13509-13.

PubMed Abstract | Publisher Full Text | Free Full Text

53. Workman A, Heaton M: Table S1. MALDI-TOF MS assay design for 14 ITGB2 missense SNPs. figshare. Dataset. 2018. 


\section{Open Peer Review}

\section{Current Peer Review Status:}

\section{Version 1}

Reviewer Report 09 April 2019

https://doi.org/10.5256/f1000research.18790.r44373

(C) 2019 Beever J. This is an open access peer review report distributed under the terms of the Creative Commons Attribution License, which permits unrestricted use, distribution, and reproduction in any medium, provided the original work is properly cited.

\section{Jonathan E. Beever}

1 University of Illinois at Urbana-Champaign, Urbana, IL, USA

2 University of Tennessee Institute of Agriculture, Knoxville, TN, USA

This is an excellent manuscript. The work is very well done and the conclusions drawn are well thought out. This manuscript will be well-sited from a scientific standpoint and the results are very translatable.

Comments:

In the Abstract -- 'Background' perhaps add bovine as in " ...binds to the CD18 receptor on bovine leukocytes, ..." followed by "Binding of Lkt to bovine CD18 results from an intact 22-amino acid signal peptide which remains uncleaved in all ruminant species." Although these are minor changes, they reflect the knowledge that this binding phenomenon is described specifically in cattle and is now inferred in other susceptible ruminant species based on the Lkt/SD18 signal peptide binding studies in cattle.

A similar argument could also be applied to the beginning of the second paragraph of the Introduction. However, this paragraph is better in its logical progression.

It is completely unclear as to why the whole-genome sequencing of the BL3 cell line was performed. Suggest removing that section from the M\&M.

Is the work clearly and accurately presented and does it cite the current literature? Yes

Is the study design appropriate and is the work technically sound? Yes

Are sufficient details of methods and analysis provided to allow replication by others? Yes 


\section{If applicable, is the statistical analysis and its interpretation appropriate? Yes}

Are all the source data underlying the results available to ensure full reproducibility? Yes

Are the conclusions drawn adequately supported by the results?

Yes

Competing Interests: No competing interests were disclosed.

Reviewer Expertise: Molecular genetics of livestock species.

I confirm that I have read this submission and believe that I have an appropriate level of expertise to confirm that it is of an acceptable scientific standard.

Reviewer Report 06 March 2019

https://doi.org/10.5256/f1000research.18790.r44372

(C) 2019 Neibergs $\mathbf{H}$. This is an open access peer review report distributed under the terms of the Creative Commons Attribution License, which permits unrestricted use, distribution, and reproduction in any medium, provided the original work is properly cited.

\section{Holly L. Neibergs}

Department of Animal Sciences, Washington State University, Pullman, WA, USA

The authors have presented a well written article describing a nicely designed and thorough set of experiments to determine if variants in the CD18 signal peptide gene (ITGB2) effect Lkt binding in leukocytes. Lkt is a protein secreted by $M$. haemolytica that activates an inflammatory response leading to fibrinous bronchopneumonia in cattle. $M$. haemolytica is an important bacterial pathogen associated with bovine respiratory disease that causes the death of over one million cattle annually in the U.S. alone. This article provides a better understanding of the molecular mechanisms involved in $M$. haemolytica infection that may lead to more effective means to prevent and treat this common disease in cattle.

Suggested minor edits were very few:

Page 3, line 1 of paragraph 1; insert "one of" after "Manheimia haemolytica is"

Page 6, line 10 of paragraph 2; replace "at run" with "and run at" after (Thermo Fisher Scientific)

Page 6, line 17 of paragraph 3; remove "in" after "times"

Page 9, line 9 of paragraph 2; I am not sure I would agree that a conserved sequence with less than $20 \%$ identity is remarkable

Is the work clearly and accurately presented and does it cite the current literature? 
Yes

Is the study design appropriate and is the work technically sound?

Yes

Are sufficient details of methods and analysis provided to allow replication by others? Yes

If applicable, is the statistical analysis and its interpretation appropriate?

Yes

Are all the source data underlying the results available to ensure full reproducibility? Yes

Are the conclusions drawn adequately supported by the results?

Yes

Competing Interests: No competing interests were disclosed.

Reviewer Expertise: Genetic susceptibility to disease

I confirm that I have read this submission and believe that I have an appropriate level of expertise to confirm that it is of an acceptable scientific standard.

Reviewer Report 08 January 2019

https://doi.org/10.5256/f1000research.18790.r42342

(c) 2019 Archibald A. This is an open access peer review report distributed under the terms of the Creative Commons Attribution License, which permits unrestricted use, distribution, and reproduction in any medium, provided the original work is properly cited.

\section{Alan L. Archibald}

The Roslin Institute, Royal (Dick) School of Veterinary Studies (R(D)SVS), University of Edinburgh, Midlothian, UK

The authors have provided a clear and thorough description of their analysis of sequence variation in the bovine ITGB2 gene that encodes CD18. They have not only identified and characterised sequence variants, particularly in two exons of interest, but also tested the effect of these variants in a functional assay in respect of binding to Mannheimia hemolytica leukotoxin. The methods used are described in exemplary detail.

There would be value in noting that some of the missense variants that are a key focus of the analyses have been reported by others previously and citing the relevant rs-identifiers:

R5C rs517776076

N27K rs521222417 
R120W rs109222573

R120Q rs522421330

D128G rs445709131

Q392K rs469652717

P656L rs379267066

The authors should be encouraged to submit their new variants to the European Variation Archive that now hosts sequence variation data for non-human species now that dbSNP has ceased this service. The authors should not only submit the sequence variants but also the genotype data and frequencies. Two of the variants listed above do not appear to have survived the migration from dbSNP to EVA and may need to be resubmitted (i.e. R120W / rs109222573; Q392K / rs469652717).

There a few (very few) minor typographical errors:

5 uM rather than $5 \mu \mathrm{M}$ on page 4, column 2 line 11

a missing gap after the comma on page 6 , column 2 , line 1

$50 \mathrm{ul}$ rather than $50 \mu$ l on page 6, column 2, 5 line from the bottom

It may be appropriate to mention the contribution of Mannheimia hemolytica to "shipping fever" and note the cost of this disease and pathogen to the US cattle industry.

The authors discuss their results in the context of a report of gene editing the bovine ITGB2 gene. The paper by Shanthalingam et al. 2016 (cited as reference 15 in this manuscript) report that gene editing a single codon in the ITGB2 gene and generation of a fetus carrying the edited yielded cells that were resistant to Mannheimia hemeolytica in an in vitro assay. The current authors correctly note that there are no reports of live born calves carrying this edit in homozygous form and thus the viability of this gene edit for resistance to Mannheimia hemolytica remains unproven. However, none of the natural ITBG2 variants characterised by the authors delivers resistance. As the authors search for variation was thorough and should have identified almost all variants of useful frequency, then designing variant signal peptide sequences that are not cleaved but do not bind the leukotoxin may be the way forward. The authors' discussion of these points could be more explicit.

Is the work clearly and accurately presented and does it cite the current literature? Yes

Is the study design appropriate and is the work technically sound?

Yes

Are sufficient details of methods and analysis provided to allow replication by others? Yes

If applicable, is the statistical analysis and its interpretation appropriate? Yes

Are all the source data underlying the results available to ensure full reproducibility? Yes

Are the conclusions drawn adequately supported by the results? 
Yes

Competing Interests: I have undertaken collaborative research with Dr Smith on topics unrelated to this manuscript and we published an article together in 2009 and conference abstracts more recently.

Reviewer Expertise: molecular genetics, gene editing

I confirm that I have read this submission and believe that I have an appropriate level of expertise to confirm that it is of an acceptable scientific standard.

The benefits of publishing with F1000Research:

- Your article is published within days, with no editorial bias

- You can publish traditional articles, null/negative results, case reports, data notes and more

- The peer review process is transparent and collaborative

- Your article is indexed in PubMed after passing peer review

- Dedicated customer support at every stage

For pre-submission enquiries, contact research@f1000.com

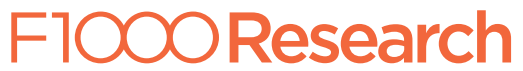

